NBER WORKING PAPER SERIES

\title{
TRADE INVOICING IN THE ACCESSION COUNTRIES: ARE THEY SUITED TO THE EURO?
}

\author{
Linda Goldberg
}

Working Paper 11653

http://www.nber.org/papers/w11653

\author{
NATIONAL BUREAU OF ECONOMIC RESEARCH \\ 1050 Massachusetts Avenue \\ Cambridge, MA 02138 \\ September 2005
}

Federal Reserve Bank of New York and NBER. Prepared for the International Seminar on Macroeconomics, National Bureau of Economic Research, Budapest June 2005. Roc Armenter, Charles Engel, Rebecca Hellerstein, Richard Portes, Cedric Tille, and participants at the ISOM meeting provided valuable comments. Eleanor Dillon provided excellent research support. The views expressed in this paper are those of the individual authors and do not necessarily reflect the position of the Federal Reserve Bank of New York or the Federal Reserve System. Address correspondences to Linda S. Goldberg, Federal Reserve Bank of NY, Research Department, 33 Liberty St, New York, N.Y. 10045. email: Linda.Goldberg@ ny.frb.org. The views expressed herein are those of the author(s) and do not necessarily reflect the views of the National Bureau of Economic Research.

(O2005 by Linda Goldberg. All rights reserved. Short sections of text, not to exceed two paragraphs, may be quoted without explicit permission provided that full credit, including $\odot$ notice, is given to the source. 
Trade Invoicing in the Accession Countries: Are They Suited to the Euro?

Linda Goldberg

NBER Working Paper No. 11653

September 2005, Revised March 2006

JEL No. F3, F4

\title{
ABSTRACT
}

The accession countries to the euro area are increasingly binding their economic activity, external and internal, to the euro area countries. One aspect of this phenomenon concerns the currency invoicing of international trade transactions, where accession countries have reduced their use of the US dollar in invoicing international trade transactions. Theory predicts that the optimal invoicing choices for accession countries depend on the composition of goods in exports and imports and on the macroeconomic fluctuations of trade partners, both bearing on the role of herding and hedging considerations within exporter profitability. These considerations yield country-specific estimates about the degree of euro-denominated invoicing of exports. I find that the exporters of some accession countries, even in their trade transactions with the euro zone and other European Union countries, might be pricing too much of their trade in euros rather than in dollars, thus taking on excessive risk in international markets.

\author{
Linda S. Goldberg \\ Research Department, 3rd Floor \\ Federal Reserve Bank-New York \\ 33 Liberty Street \\ New York, NY 10045 \\ and NBER \\ linda.goldberg@ny.frb.org
}




\section{Introduction}

The accession countries to the euro area are increasingly binding their economic activity, external and internal, to the euro area countries. One aspect of this phenomenon concerns the currency invoicing of international trade transactions. There has been a substantial shift away from the use of the US dollar in accession country international trade transactions. In this paper, I explore the theoretical drivers of optimal invoicing choices for exporters, highlighting the importance of the composition of goods in exports and imports, and the partner composition of these forms of trade. I explore whether accession country exporters, by invoicing in euros and thus closely aligning their trade with that of the rest of the euro area, are pursuing economically appropriate strategies. Perhaps some of the accession country export transactions are not as well suited to euro invoicing, leading producers with overly high euro shares in pricing to expose themselves to excessive risk in international markets.

The analysis draws on lessons from the theoretical model of Goldberg and Tille (2005), which presents the determinants of the relative importance of hedging motives and herding motives in currency invoicing (and exchange rate pass through) choices by exporters. This model motivates an empirical application to the accession countries. The model shows the role of macroeconomic volatility and industry composition in exporter pricing strategies, demonstrating that optimal currency invoicing strategies consist of a mix of hedging considerations and herding. Macroeconomic volatility considerations have been emphasized in a range of papers, from Giovannini (1988) through recent contributions by Devereux, Engel and Storegaard (2004), Oi, Otani, and Shirota (2004), and Engel (2005). By introducing an explicit role for elasticities of substitution in demand and decreasing returns to scale in pricing, Bacchetta and van Wincoop (2005) and Goldberg and Tille (2005) [GT] show that macroeconomic volatility may mainly play a role in pricing and currency invoicing decisions for differentiated products. ${ }^{1}$ Instead, they stress that industry structure, emphasized early on by McKinnon (1979), is the key determinant of how much herding occurs in pricing and currency invoicing decisions. Producers in highly competitive industries, and producers facing a high degree of decreasing returns to scale in production, may optimally mimic the pricing strategies of their competitors in markets in which

\footnotetext{
${ }^{1}$ While Bacchetta and van Wincoop discuss this herding motive in the case where the exchange rate is the only source of volatility, Goldberg and Tille also include volatility in wages and foreign demand. Campa and Goldberg (2005) and Campa, Goldberg, and Gonzalez-Minguez (2005) show that macroeconomic volatility is less important than industry features in determining exchange rate pass through into import prices.
} 
their goods are sold. This leads to herding in invoice currency selection, while not explicitly seeking to identify which currencies will be used in such herding. Various strategies have been offered elsewhere to pin down the equilibrium choice of herding currency. One example is through introducing "network externalities" in foreign exchange markets interacting with transaction costs in securities markets, as in Portes and Rey (1998). Using reasonable ranges of parameters, GT show that this herding activity could be much more important in decision making than the influence of hedging and macroeconomic volatility.

These considerations are applied to the trade transactions of eleven countries aspiring to join the euro area: Bulgaria, Cyprus, the Czech Republic, Estonia, Hungary, Latvia, Lithuania, Malta, Poland, Slovakia, and Slovenia. A simple picture drawn from GT motivates the focus of the paper, which explores the extent to which accession country exporters use dollars, euros, or other currencies in invoicing their international trade transactions. Using mostly data for 2002, GT compared the actual share of dollar use in invoicing country exports to what might be "expected" purely on the basis of trade with the United States and the composition of country trade. The pattern of this relationship for a broad sample of countries is shown in Chart 1.

Chart 1 works with the assumption that all exports to the United States and all exports of "referenced priced" and "organized-exchange" traded goods ("RW goods") to other countries are invoiced in dollars, the standard currency for pricing most of these transactions. If this assumption were true, a country would have its observations lie along the 45 degree line in this figure. Observe that many of the accession countries have invoicing patterns above the 45 degree line, suggesting that they have fewer exports invoiced in dollars compared with what would be predicted by this simple metric. Estonia, Slovenia, Slovakia, Hungary, and the Czech Republic all fit this description. The exception is Latvia which, like Greece, had considerably more use of dollars in invoicing exports than expected purely on the basis of Latvia's trade with the United States and exports of highly substitutable goods.

What are the consequences of exporters making invoice currency choices that are inappropriate, given observed industry features and the volatility of macroeconomic conditions? These choices would lead to lower expected profits and more volatile profits than are optimal. As a hypothetical, consider the case of an accession country exporter invoicing in euros while competitors in euro area countries or in the United States are invoicing in dollars. Suppose as well that there is a high degree of product substitutability between the exporter's goods and its 
competitors' goods. With fluctuations in exchange rates, the exporter's relative price will vary ex post, even if ex ante the common currency expected prices of the goods were identical.

\section{Chart 1: Vehicle currency use of the dollar and "commodity" type exports}

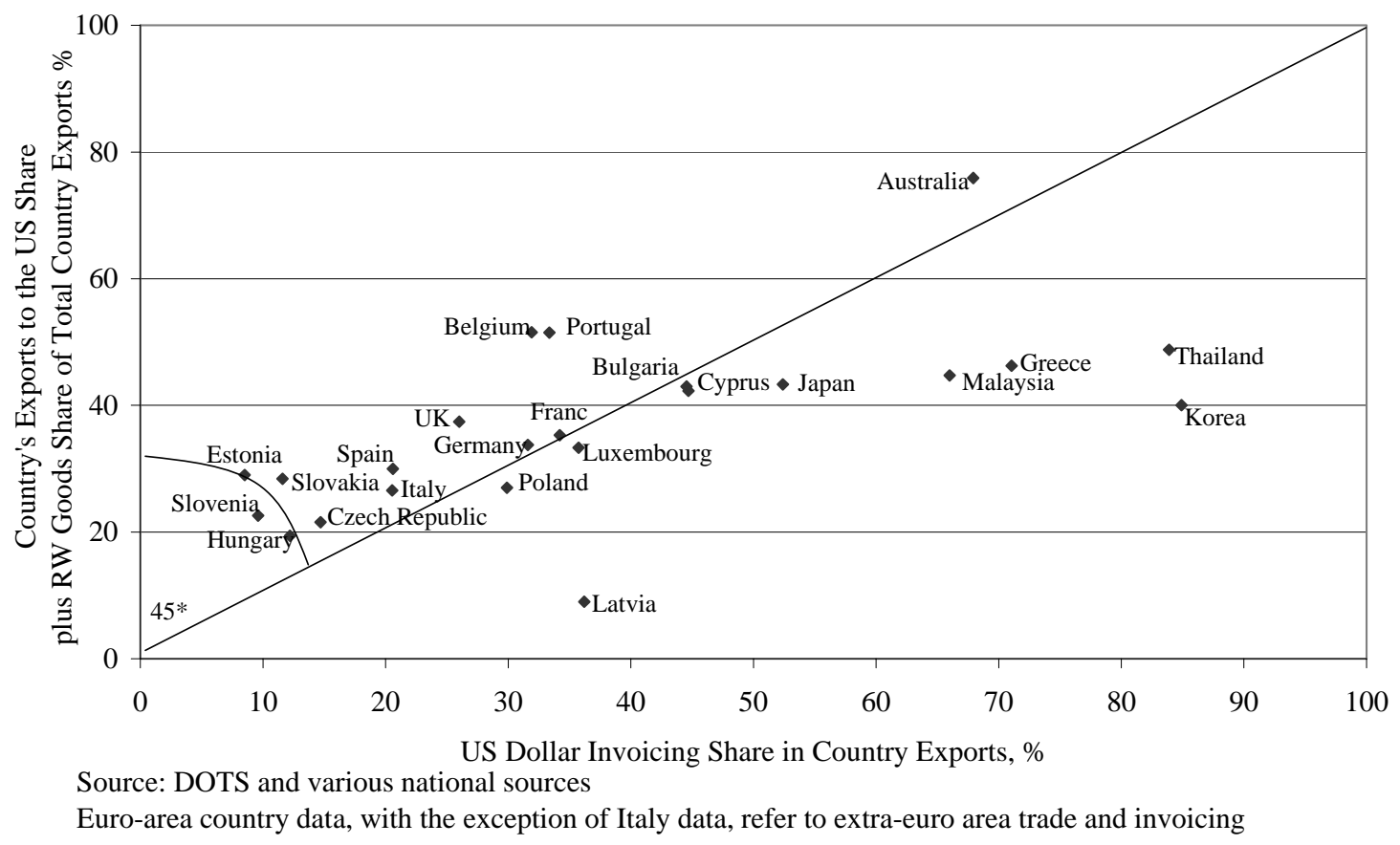

Reproduced from Figure 5, Goldberg and Tille (2005). 2002 data used.

An unanticipated dollar appreciation against the euro would lead the exporter to experience a sharp increase in demand for its goods. Given decreasing returns to scale, the exporter would also have an increase in his marginal costs. The net effect on expected profitability will depend on the elasticities of substitution, the returns to scale in his production function, and a mix of covariances between the revenue and cost conditions he faces. In the reverse case of an unexpected dollar depreciation against the euro, the exporter's goods are ex post excessively expensive, leading to extensive substitution away from his products.

This example shows that, even in cases where accession country exporters are overwhelmingly trading with euro area countries, dollars may still be more appropriate for invoicing trade with the euro area for those goods on which dollars are vehicle currencies for pricing. Indeed, exporters in euro area countries use dollars for invoicing similar products even on trade transactions within the euro area, as recently discussed by the European Central Bank (ECB, 2004). 
Exploring these questions for the accession countries starts with the model and lessons of the optimal invoicing currency work of Goldberg and Tille (2005). After briefly presenting the theoretical motivation (section II), I present empirical detail on the direction of trade of accession countries with respect to euro area countries, the rest of the European Union, the United States markets, and other "dollar bloc" countries, followed by detail on the product composition of accession country exports and imports. For this work the Rauch (1999) indices, constructed to highlight the role of types of networks used in goods market transactions, are applied to detailed accession country export and import data. This application produces shares of goods in trade that are best described as differentiated, referenced priced, or priced in and traded on organized exchanges. Organized exchange trade goods, such as commodities, are assumed to be highly substitutable and the theory predicts that producers of such goods should herd in their invoicing choices. In practice, the dollar typically has been the currency used in such herding, at least in post war transactions. Conceptually, as long as this remains the case, the share of these types of goods in exports is treated as a lower bound on dollar invoicing.

The paper's focus next turns to the second consideration: the role of hedging in optimal invoicing decisions by exporters. The theory predicts that optimal hedges should cover expected shocks to producer marginal costs. In other words, for stable expected profits, a producer should invoice in a currency that yields positive revenue shocks at the same time that the producer faces high marginal costs, either because wages fluctuate or because aggregate demand fluctuates in an environment of non-constant returns to scale. An invoice currency should be selected for hedging purposes if it provides the highest covariance between an exchange rate (on the producer export revenue) and marginal costs, or if it helps limit demand for a product at precisely the time when marginal costs of production are high. Thus, revenue will be high just at the times that marginal costs are high. For each country, we explore whether the dollar or the euro better suits this objective in export transactions to the United States, to the euro area, or to the rest of the European Union.

A number of interesting observations are generated based on this analysis. First, there is considerable cross-country heterogeneity in the portion of exports invoiced in dollars versus in euros. On average, more than half of the exports of accession countries are invoiced in euros, while the average share of exports invoiced in dollars is closer to 25 percent. Euro use has been increasing, with some of this euro gain matched by declines in dollar use in export invoicing. 
Indeed, dollar use as an invoicing currency has declined even for some countries that initially had surprisingly low use of dollars by the rough analytical metrics of the paper. On accession country exports to countries other than the United States and the euro area, euro invoicing is roughly 37 percent, a lower share than observed for euro area countries. ${ }^{2}$

The United States is not a major export destination for the goods of most accession countries, typically receiving less than 5 percent of these exports. Most of the accession country exports go to the euro area and the rest of Europe. Between 60 and 85 percent of the total exports of accession countries are characterized as differentiated products. While the remaining exports are often in reference priced goods, for example paper, some countries also export substantial amounts of organized exchange traded goods like copper and aluminum. Much of the latter types of exports have dollar pricing worldwide. Controlling both for the structure of partners in trade and the composition of traded goods products, some accession countries use euros more heavily and use dollars less frequently in invoicing than do euro area countries.

Examination of the optimal currencies in invoicing for hedging purposes also yields interesting conclusions for accession country exports to the United States, the euro area, the rest of the European Union, and Asia. The covariance analysis for this work compares the desirability of invoicing in euros versus dollars in exports to each destination market. In most cases, neither the dollar or the euro are appropriate choices for hedging the demand and marginal cost risks to profits from exporter perspectives. Lithuania significantly favored the dollar as a hedging currency prior to 2000, but this relationship then disappeared. Since 2000, neither the dollar or euro was theoretically a strong hedge, except in the limited case of Hungarian exports to Asia, which would have favored the euro. Mostly, based on hedging, exporters in accession countries would be indifferent to the euro or dollar as an invoice currency choice on their exports to Europe, the United States, and Asia.

Overall, if the dollar is the key vehicle currency for many countries on goods we call reference priced and exchange traded, our results suggest that some accession countries may have moved further toward the euro in trade invoicing than is potentially optimal. This argument relies, in part, on an assumption that the dollar has retained a central role as a vehicle currency in the goods that are reference priced and traded on organized exchanges. The validity of this

\footnotetext{
${ }^{2}$ Small countries typically have low use of their own currencies in international trade transactions, as reported in Goldberg and Tille (2005). The two accession countries that report this information, the Czech Republic and Latvia, use their home currency on invoicing less than 10 percent of their imports and exports.
} 
assumption, and its relation to exchange rate regimes, is discussed in the concluding remarks of section IV.

\section{A three-country / three currency model of invoice currencies}

The theoretical exposition closely follows the model of Goldberg and Tille (2005) [GT] on currency choice for trade invoicing. As exposited above, GT develop the interaction between industry features and macroeconomic variability in a new open-economy macro model with three countries and price rigidities, building on both Devereux, Engel and Storegaard [DES] (2004) and Bacchetta and van Wincoop (2005). While GT do not derive a general equilibrium version of the DES model, they extend the existing theory of invoice currency selection in several critical dimensions. First, GT move from the DES two-country / two-currency world to a three-country / three-currency one, allowing for invoicing in a vehicle currency that belongs neither to the exporter nor the importer home market. Second, GT develop the contrasting roles in optimal invoice currency selection of industry characteristics, such as the substitutability between competitors' goods, and macro-economic factors, such as business cycle and exchange rate volatility. The firm's incentive to limit the fluctuations of its relative price by choosing a trade invoicing strategy close to that of its competitors leads to a type of 'herding' behavior in invoice currency choices for the exporters of relatively homogeneous products. This feature is also emphasized in Bacchetta and van Wincoop (2005). Third, GT introduce decreasing returns to scale in production, so that increases in output increase marginal costs even when wages are not responsive.

Overall, GT conclude that macroeconomic variability is an important consideration in optimal invoicing only for trade in differentiated products. The degree of macroeconomic volatility needed to disturb an invoicing status quo for trade in more homogeneous products would need to be exceptionally large. The theoretical prediction is that -- even within a country where all economic agents face the same degree of macroeconomic volatility-- different producers will make different invoice currency choices. Moreover, an exporter with two distinct trading partners is more likely to use distinct currencies on invoicing his exports to these distinct partners when his production is in differentiated goods and when he faces lower levels of decreasing returns to scale in production. 
The model set-up. Before turning to the empirical implementation for accession countries, this section presents an abridged version of GT. An exporting firm is assumed to have to post a price for its goods before knowing the realization of various shocks affecting the economy. The exporter is located in country $e$, produces a brand $z$, and sells her goods to the destination country $d$. Goods are produced using a technology with decreasing returns to scale:

$$
Y_{e d}(z)=(\alpha)^{-1}\left[H_{e d}(z)\right]^{\alpha} \quad, \quad 0<\alpha \leq 1
$$

where $Y_{e d}(z)$ is the output of $z, H_{e d}(z)$ is the labor input, and $\alpha$ is the returns to scale parameter. The firm faces the following demand in destination country $d$ :

$$
Y_{d}(z)=\left[P_{e d}(z) / P_{d}\right]^{-\lambda} C_{d}
$$

where $C_{d}$ is the total demand for brands of the relevant sector in country $d, P_{e d}(z)$ is the price, in country $d$ currency, of the brand $z$ produced in country $e$, and $P_{d}$ is the price index, in country $d$ currency, across all brands of the relevant sector sold in country $d . \lambda>1$ is the elasticity of substitution between the various brands. According to (2), the demand for a specific brand depends on its price, relative to the prices of other brands in the sector, and on the strength of overall demand in the destination market.

The exporter producing brand $z$ sets its price in currency $k, P_{e d}^{k}(z)$, before the realization of the shocks affecting the economy. The currency of invoicing can be the currency of the country in which the exporter is located $(k=e)$, the currency of the country of destination $(k=d)$, a third vehicle currency $(k=v)$, or a combination of these three currencies. The exporter's price is set in currency $k$ to maximize expected profits represented by (3):

$$
\Pi_{e d}^{k}(z)=E D_{e}\left\{S_{e k} P_{e d}^{k}(z)\left[\frac{S_{e k} P_{e d}^{k}(z)}{S_{e d} P_{d}}\right]^{-\lambda} C_{d}-W_{e}(\alpha)^{\frac{1}{\alpha}}\left[\left[\frac{S_{e k} P_{e d}^{k}(z)}{S_{e d} P_{d}}\right]^{-\lambda} C_{d}\right]^{\frac{1}{\alpha}}\right\}
$$

where $S_{e k}$ is the exchange rate between currency $e$ and currency $k$, in terms of units of currency $e$ per unit of currency $k$ so that an increase corresponds to a depreciation of currency $e . D_{e}$ is the state-specific discount factor at which profits are evaluated, and $W_{e}$ is the nominal wage. With 
its price set in currency $k$, the unit revenue for the exporter in currency $e$ is $S_{e k} P_{e d}^{k}(z)$. Similarly, the price in currency $d$ paid by consumers in the destination country is $\left[S_{e d}\right]^{-1} S_{e k} P_{e d}^{k}(z)$.

Optimal invoice currency selection. Maximized profits are obtained through the exporter choice of the currency $k$ in which her goods are invoiced. In making this selection, the exporter regards all the other variables in (3), such as the destination market demand, exporter wages, aggregate prices in the destination market and the bilateral exchange rate as exogenous to her invoicing decision, with lower case variables denoting log deviations from the steady state ( $x=\ln X-\ln X_{s s}$ ). Without constraining the exporter to invoice entirely in any currency $e, d$ or $v$, the invoicing decision is a choice of weights of the three available currencies in the invoicing currency basket $k$. Specifically, the weights of currencies $d$ and $v$ in the invoicing of exports to country $d$ are $\beta_{d}^{d}$ and $\beta_{d}^{v}$ respectively, with the weight of currency $e$ being $1-\beta_{d}^{d}-\beta_{d}^{v}$, and with the sum of the weights bounded between 0 and 1 . The case of pricing in one currency only is given by setting the weights to 0 or 1 . Specifically, producer currency pricing (PCP), which corresponds to the producer keeping unit revenues fixed in his own currency, corresponds to $\beta_{d}^{d}=\beta_{d}^{v}=0$. Local currency pricing (LCP), in which the producer has unit revenue stabilized in the buyer's currency, corresponds to $\beta_{d}^{d}=1, \beta_{d}^{v}=0$. Vehicle currency pricing (VCP) is given by $\beta_{d}^{d}=0, \beta_{d}^{v}=1$.

The sensitivity of $p_{d}$, the relative price between brand $z$ and the competing brands, , to exchange rate movements plays a central role in the invoice currency choice. Some brands are invoiced in currency $d$, so the price paid by the consumers for these brands is unaffected by exchange rate movements. Other brands are invoiced in currency $e$, and the consumer price in currency $d$ moves with the exchange rate between the two currencies, $s_{e d}$, with consumer paying a higher price when currency $e$ appreciates (i.e $s_{e d}<0$ ). A final set of brands are invoiced in currency $v$, so the price paid by consumers is higher when currency $v$ appreciates (i.e. $\left.s_{e d}-s_{e v}<0\right)$. We denote the total share of competing brands invoiced in currency $d$ by $\eta_{d}^{d}$, and the shares invoiced in currency $e$ and $v$ by $\eta_{d}^{e}$ and $\eta_{d}^{v}$ respectively. In this case, the exporter's relative price of the good sold in the destination market becomes: 


$$
q_{e d}^{k}=\left(\beta_{d}^{d}-\eta_{d}^{d}\right) s_{e d}+\left(\beta_{d}^{v}-\eta_{d}^{v}\right) s_{e v}
$$

Expression (4) shows that, while stabilization of unit revenues requires $\beta_{d}^{d}=1$, full stabilization of his relative price instead requires an exporter to choose weights on the different currencies that exactly correspond to their shares in the industry wide price index: $\beta_{d}^{d}=\eta_{d}^{d}, \beta_{d}^{v}=\eta_{d}^{v}$. However, stabilization of the relative price is not the only consideration driving the exporter's decision.

Optimal invoicing weights $\beta_{d}^{d}$ and $\beta_{d}^{v}$ maximize expected profits under the constraint that $\beta_{d}^{d}, \beta_{d}^{v}$ and $\beta_{d}^{d}+\beta_{d}^{v}$ do not fall outside the [0,1] interval and given the structure of demand and costs shocks to which the exporter is subjected. GT show that the optimal invoicing basket solution for the case where an exporter is selling only to one destination market is: ${ }^{3}$

where:

$$
\begin{aligned}
& \beta_{d}^{d}=\Omega \eta_{d}^{d}+(1-\Omega) \rho\left(m_{e d}, s_{e d}\right) \\
& \beta_{d}^{v}=\Omega \eta_{d}^{v}+(1-\Omega) \rho\left(m_{e d}, s_{e v}\right) \\
& \beta_{d}^{e}=1-\beta_{d}^{d}-\beta_{d}^{v}=(1-\Omega)+\Omega \eta_{d}^{e}-(1-\Omega)\left[\rho\left(m_{e d}, s_{e d}\right)+\rho\left(m_{e d}, s_{e v}\right)\right]
\end{aligned}
$$

$$
\Omega=\frac{\lambda(1-\alpha)}{\alpha+\lambda(1-\alpha)} \quad, \quad m_{e d}=w_{e}+\frac{1-\alpha}{\alpha} c_{d}
$$

The term $m_{e d}$ entering into equations (5)-(7) is a covariance reflecting the influence of exogenous factors, for example exporter wages, productive inputs, and destination market aggregate demand, on the firm's marginal cost. Because of decreasing returns to scale, a 1 percent increase in demand requires a $1 / \alpha$ percent increase in the labor input, hence a $1 / \alpha$ percent increase in cost, holding the wage constant. The increase in demand also leads to a 1 percent increase in revenue, holding the price constant. The net increase in the marginal cost is then $1-1 / \alpha=(1-\alpha) / 1$ percent. The terms $\rho\left(m_{e d}, s_{e d}\right)$ and $\rho\left(m_{e d}, s_{e v}\right)$ in (5)-(7) are regression coefficients that capture the covariances between marginal cost, $m_{e d}$, and the exchange rates $s_{e d}$ and $s_{e v}$.

\footnotetext{
${ }^{3}$ Goldberg and Tille (2005) derive a similar set of intuitions for the case where the exporter is constrained to use a single currency, rather than a basket of currencies, in his optimal selection. The results are qualitatively the same.
} 
Components of optimal invoicing. While invoicing in the exporter's currency has the advantage of fully stabilizing the exporter's marginal revenue, this full stabilization $\left(\beta_{d}^{e}=1\right)$ is not necessarily an optimal choice for two reasons shown in equations (5)-(7). The first reason reflects a "herding” motive, captured by the terms $\Omega \eta_{d}^{d}$ and $\Omega \eta_{d}^{v}$. The exporter optimally limits the movements of her relative price by choosing an invoicing strategy close to that of her competitors: the exporter places a higher weight on invoicing in the destination currency, $\beta_{d}^{d}$, when her competitors have a higher share $\eta_{d}^{d}$ of their own sales invoiced in that currency.

The second motive for a producer to move away from PCP is due to "hedging", as captured by the terms $(1-\Omega) \rho\left(m_{e d}, s_{e d}\right)$ and $(1-\Omega) \rho\left(m_{e d}, s_{e v}\right)$. These terms measure the potential for an exporter to have an invoicing strategy that helps profits by limiting the impact of fluctuations in marginal costs on her profits. If she invoices in the destination currency, $d$, a depreciation of her currency vis-à-vis the destination currency $\left(s_{e d}>0\right)$ increases unit revenue, in her own currency. If depreciations of this exchange rate tend to be correlated periods of increases in marginal costs, i.e. $\rho\left(m_{e d}, s_{e d}\right)>0$, invoicing in the destination currency induces a positive correlation between marginal revenue and marginal costs, reducing some of the volatility in profits. A similar logic applies to the vehicle currency. Indeed, if we were to consider alternative vehicle currencies for use in an export transaction, the model implies that the hedging portion of the invoicing decision should favor the currency (i.e. the bilateral exchange rate) that is significantly and most positively correlated with the shocks to exporter costs, regardless of whether these arise through prices of imported inputs, local currency wages, or fluctuations in aggregate destination market demand.

The balance of influence on the herding dimension versus the hedging dimension in (5)(7) is given by the term $\Omega$, which solely reflects the structural parameters of the model, namely the elasticity of substitution between goods, $\lambda$, and the degree of returns to scale, $\alpha$. The herding dimension is more pronounced ( $\Omega$ is large) in industries where goods are more substitutable ( $\lambda$ is large), since movements in relative prices then leads to large fluctuations in quantities sold. 
The effect is also stronger when the technology exhibits larger decreasing returns to scale ( $\alpha$ is small), because fluctuations in output generate large movements in marginal cost. ${ }^{4}$

Clearly, this theoretical exposition argues that optimal invoicing has both countryspecific and industry-specific considerations. The country-specific macroeconomic correlations mainly apply to the exporters of highly differentiated products. By contrast, exporters in industries producing a more homogenous good (i.e. goods that are more substitutable with those of their competition) would optimize by following industry practices and invoicing in a basket of currencies close to that of their competitors. ${ }^{5}$

\section{Invoicing Trade for Accession Countries}

A recent ECB report ${ }^{6}$ provides data on euro invoicing of imports and exports for eight euro zone countries (Belgium, France, Germany, Greece, Italy, Luxembourg, Portugal, and Spain), all ten newly accepted countries to the European Union (Cyprus, the Czech Republic, Estonia, Hungary, Latvia, Lithuania, Malta, Poland, Slovakia, and Slovenia), and Bulgaria, a European Union candidate country. In the analysis below, Bulgaria is included with the "euro area accession countries”, misusing the terminology for brevity purposes.

The ECB data run from 2000 to 2003, with less complete coverage across countries in the early years. The data from the ECB report are supplemented with data on euro, dollar, and local country invoicing gathered from individual country sources, as detailed in the appendix tables of Goldberg and Tille (2005). The accession country data are presented in Table 1, with the top panel providing broad details for 2000, and the lower panel providing details for 2002, the last year for which dollar invoicing data are widely available.

\footnotetext{
${ }^{4}$ If we were operating in an environment of increasing returns to scale, with $\alpha$ bounded by negative 1 and zero, the role of $\lambda$ would be damped as the degree of scale economies in production rises. The effect of an increase in returns to scale, i.e. an $\alpha$ that is more negative, is an unambiguous reduction in the invoicing weight on herding.

${ }^{5}$ This theoretical exposition has focused on invoice currency choice when prices are sticky over the invoicing interval. Of course, in some cases flexible prices may better match reality. In this case, our lessons still hold since there is a direct parallel between optimal invoice currency selection and observed levels of exchange rate pass through into traded goods prices [Goldberg and Tille (2005) and Engel (2005)]. There is a direct correspondence between models of optimal invoice currency selection under sticky prices and those of partial exchange rate pass through in the case of flexible prices.

${ }^{6}$ Review of the International Role of the Euro, Jan 2005.
} 
Table 1: Dollar and Euro Shares of Trade Invoicing in Accession Countries

\begin{tabular}{|c|c|c|c|c|}
\hline \multicolumn{5}{|c|}{ Invoicing Patterns in 2000} \\
\hline & \multicolumn{2}{|c|}{ Exports } & \multicolumn{2}{|c|}{ Imports } \\
\hline & Euro Share & Dollar Share & Euro Share & Dollar Share \\
\hline average: & 46.0 & 39.3 & 48.5 & 37.8 \\
\hline Bulgaria & 37.0 & 60.1 & 47.0 & 50.2 \\
\hline Czech Republic* & 65.4 & 14.1 & 63.1 & 19.7 \\
\hline Latvia** & 35.5 & 43.6 & 35.5 & 43.6 \\
\hline \multicolumn{5}{|c|}{ Invoicing Patterns in 2002} \\
\hline & \multicolumn{2}{|c|}{ Exports } & \multicolumn{2}{|c|}{ Imports } \\
\hline & Euro Share & Dollar Share & Euro Share & Dollar Share \\
\hline average: & 58.6 & 23.1 & 58.5 & 27.6 \\
\hline Bulgaria & 52.0 & 44.5 & 60.0 & 37.1 \\
\hline Cyprus & 21.8 & 44.7 & 45.5 & 34.9 \\
\hline Czech Republic & 68.8 & 14.7 & 65.0 & 19.5 \\
\hline Estonia† & 70.0 & 8.5 & 61.0 & 22.0 \\
\hline Hungary & 83.0 & 12.2 & 73.0 & 18.5 \\
\hline Latvia ** & 47.7 & 32.1 & 47.7 & 32.1 \\
\hline Lithuania $†$ & 22.0 & & 53.0 & \\
\hline Malta & & & 34.7 & 48.8 \\
\hline Poland & 60.0 & 29.9 & 60.0 & 28.6 \\
\hline Slovakia & 73.9 & 11.6 & 60.1 & 21.2 \\
\hline Slovenia & 87.0 & 9.6 & 83.0 & 13.3 \\
\hline
\end{tabular}

Accession countries invoice their imports and exports largely in euros, with an average euro share well over 50 percent in 2002. However, the cross-country variation in the role of the euro in export invoicing is large, ranging from below 25 percent for Cyprus and Lithuania to over 60 percent for the Czech Republic, Estonia, Hungary, Poland, Slovakia, and Slovenia. With exception of Cyprus, the data indicate a significantly smaller share of exports and imports invoiced in U.S. dollars. Most accession countries do not report local currency invoicing shares. The two countries that do, the Czech Republic and Latvia, report home currency shares for imports and exports at or below 10 percent. Since the sum of euro and dollar are closer to 80 percent than 100 percent for some countries (Cyprus, Czech Republic, Estonia, Latvia, for 
example), it is evident that currencies other than the dollar and euro still play a role in invoicing trade.

Among these countries, only a few have invoicing data published both for 2000 and 2002, thereby providing only a limited perspective on how invoicing patterns are changing over time. The available data are consistent with the euro growing in its role as the currency used in invoicing both export and import transactions. This pattern is shown in Chart 2, where the left most bars indicate the increase in average annual euro use in invoicing the exports of the accession countries for which we have 2000 and 2002 data. To provide perspective on these developments, in the right-most bars I introduce comparable information for the euro area countries. ${ }^{7}$ Among the three accession countries reported, the biggest increase in euro share over 2000 through 2002 is for Bulgaria, at almost 8 percent annually, followed by Latvia at 6 percent, and the Czech Republic at under 4 percent. The increase in euro use on export invoicing by euro area countries has been within a similar range over this time frame, again with variation across countries. Referring back to Chart 1, only Greece and Latvia had an increase in euro use in invoicing that might be expected based on the prior "unexplained” large vehicle role of the dollar in its exports. ${ }^{8}$

\footnotetext{
${ }^{7}$ The data for the accession countries and Italy cover all exports, while the data for the other euro area countries cover extra-euro area exports only.

${ }^{8}$ Appendix Table 1 provides the raw data on invoicing for euro area countries.
} 
Chart 2: Average Annual Rise in Euro Invoicing of Exports, 2000-2002*

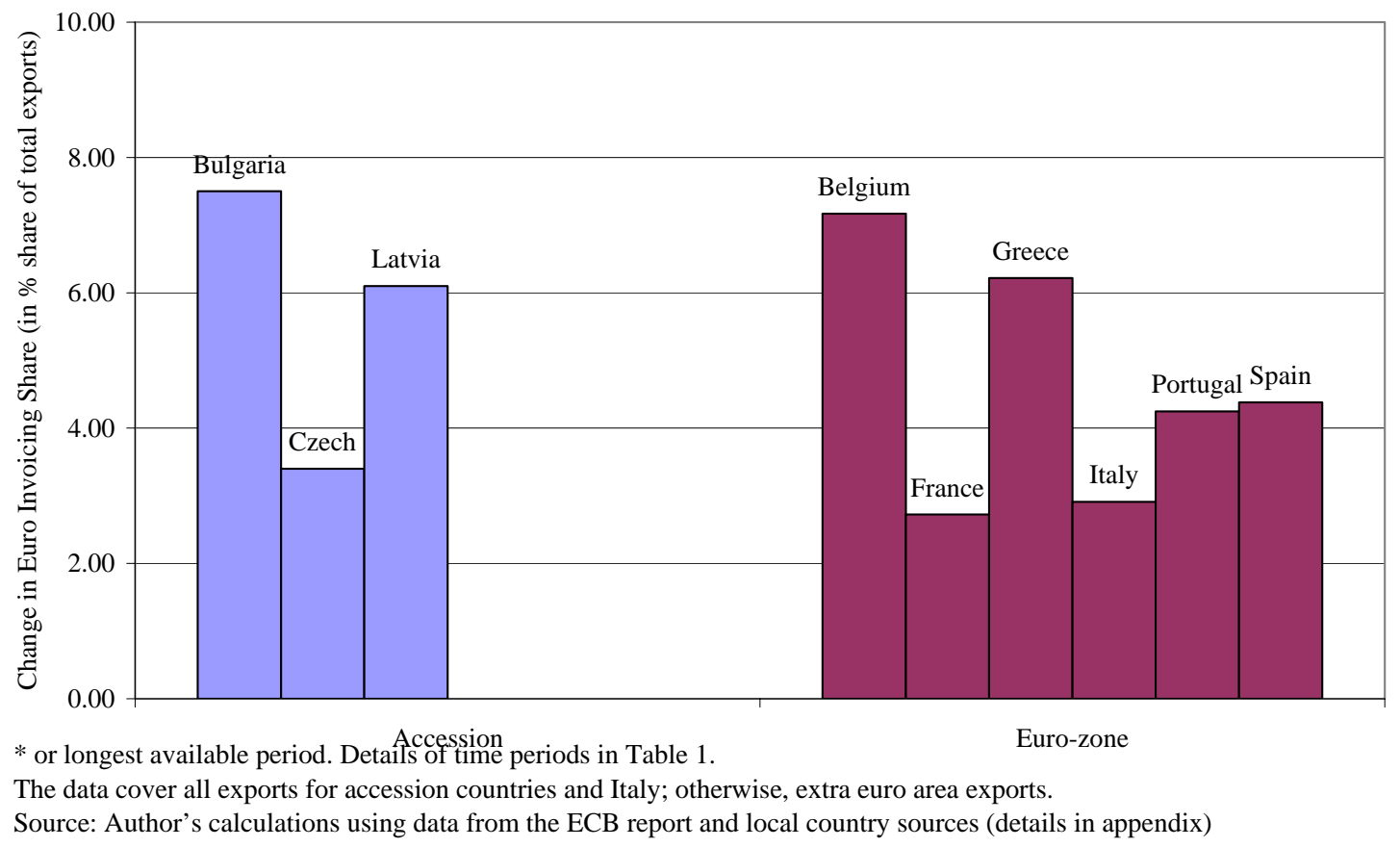

Chart 3 shows the extent to which increasing uses of euros in export invoicing came through reduction in the use of U.S. dollars for these purposes. For those countries for which relevant information is available, there has been both an (average annual) increase in the euro and an (average annual) decline in the dollar in export invoicing. Among the three accession countries for which there is appropriate data, euro gains have roughly matched dollar declines for Bulgaria and Latvia. For the Czech Republic, where dollar share in invoicing started low, increased euro use came through reduced use of other currencies. The experience among the euro area countries has also been mixed. For Greece, Spain and Italy, most of the increase in euro use came in parallel to reduced use of dollars. This was not the case for France, and was only partially the case for Portugal. 
Chart 3: Average Annual Rise in Euro Invoicing and Fall in Dollar Invoicing of Exports, 2000-2002

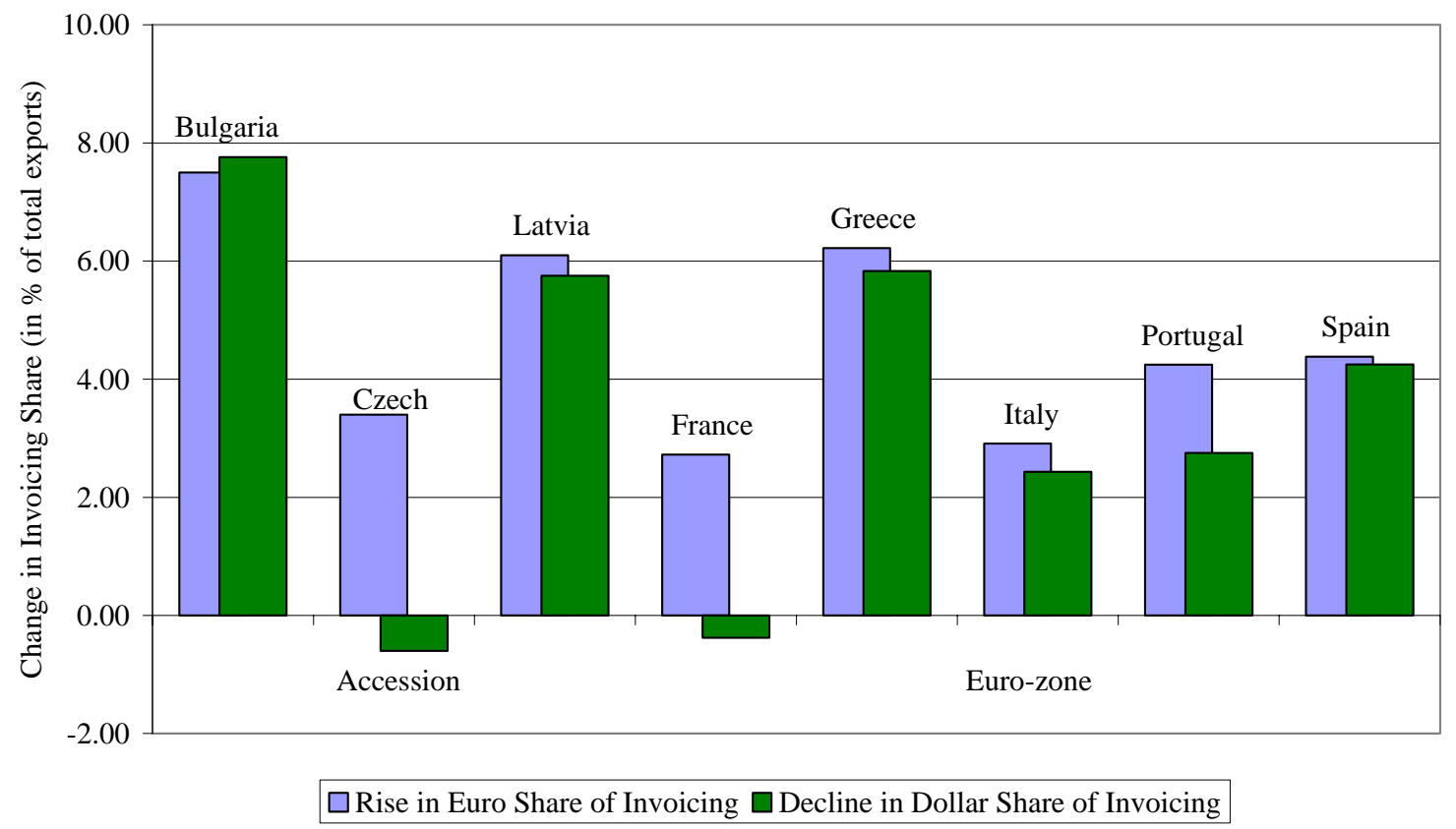

Source: Author's calculations using data from the ECB report and local country sources (details in appendix)

These changes in invoicing patterns may be consistent with a number of complementary hypotheses. First, there may be an increased prominence of the euro area and rest of Europe, or a decline in the United States or dollar bloc countries, as a destination for exports. Second, the increase in euro use and related decline in dollar use may be because accession countries have reduced the share of commodity type goods in their exports. Third, these changes may be driven by producer optimization under changing covariance structures in macroeconomic fluctuations. Alternatively, there may have been a switch in market invoicing behavior from use of dollars to use of euros on the same products, with the same partners. ${ }^{9}$ This change in behavior might occur because of a change over time in macroeconomic correlations, highlighted in equations (5)-(7), with such changes possibly induced by shifts in exchange rate regimes. By addressing these

\footnotetext{
${ }^{9}$ Another, more mundane explanation is that these results are purely due to translation effects from changes in the dollar-euro exchange rate between 2000 and 2002. The valuation effects due to the strong dollar during 2000 made the dollar value of exports disproportionately high for euro area countries. If the invoicing data are based on nominal values, not real quantities, the decline in the dollar against the euro through 2002 could reduce the measured dollar invoicing share, even if actual invoicing patterns were unchanged. The dollar appreciated by 3.1 percent from 2000 to 2001 and depreciated by 5.6 percent in 2002. The cumulative change from 2000 to 2002 was a dollar depreciation of 2.3 percent, much smaller than the total average declines in dollar invoicing of exports of 16 percent for accession countries, and 14 percent for euro area countries.
} 
hypotheses the work provides perspective on whether accession countries are invoicing as predicted by the theory and implied exporter optimization, or are potentially exposing themselves to excessive profit volatility and lower expected profits.

Destinations for Accession Country Exports. Did euro use increase in accession country trade because of increasingly close trade relationships with countries tied to the euro? Chart 4 provides data on euro share in invoicing exports versus euro area share in total accession country exports for the years 2000 (indicated with lighter points) and 2003 (darker points). If all euro area trade was invoiced in euros, and only euro area trade was invoiced in euros, the data points of this chart would lie along the 45 degree line.

The proximity of the three country-data points for 2000 to the 45 degree line indicate that initial use of euros in invoicing roughly matched shares of the euro zone countries in exports for accession countries in that year. Yet by 2003 use of the euro in invoicing accession country exports far exceeded the expanded share of the euro area in country exports. All accession countries, with the single exception of Lithuania, had euros play a larger role in export invoicing than would be expected purely due to trade with countries within the euro area (ignoring, at this point, the issue of the composition of trade, which should reduce euro use even within the area to the extent that other currencies are used in invoicing homogeneous commodities and goods). As reflected in distance from the $45 \%$ line, chart 4 shows that measured increases in euro invoicing between 2000 and 2003 well exceeded the mild increases observed in accession country exports to the euro area. 
Chart 4: Export Invoicing in Euros v. Exports to the Euro Zone, 2000 and 2003

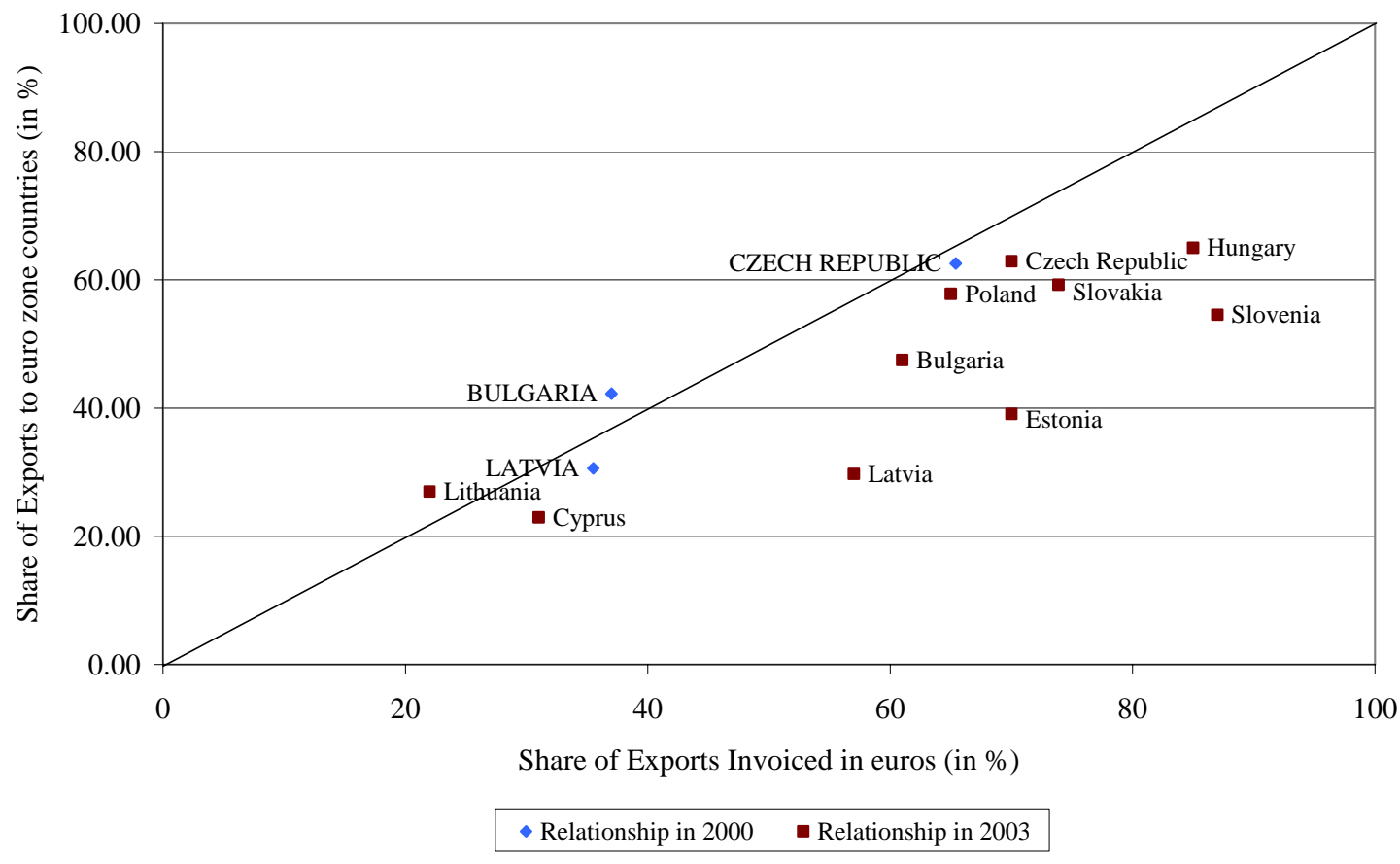

Another potential explanation is that accession country exporters are increasingly using euros to invoice exports to countries outside of the euro zone, for example to the rest of the European Union or to countries tied to the euro through exchange rate arrangements. Some of this change may be attributable to changes in the exchange rate or currency orientation of tradepartner countries. Such changes might induce changes in the structure of covariances entering the invoice currency selection criteria, or might even induce shifts in the herding currency equilibria for a particular type of good. Within these partner countries, a key related question is whether the competitors to accession country exporters are largely invoicing in euros or, for example, dollars. ${ }^{10}$

Tables 2a and 2b provide details on the concentration of accession country trade with European markets, the United States, and other countries heavily using the euro or the dollar. Table 2a shows that in 2003, the euro area accounts for between one quarter and sixty percent of accession exports. Other "euro bloc" countries are not big export destinations. Much more

${ }^{10}$ Indeed, for perhaps similar reasons that the accession countries choose to invoice trade largely in euros, many countries outside of Europe choose to invoice their exports largely in U.S. dollars. As an example of this, Goldberg and Tille (2005) show that among Australia, Japan, Korea, Malaysia, and Thailand dollar invoicing averages 73\% for imports and $75 \%$ for exports. 
influential are exports to the rest of the countries in the European Union but outside the euro area. Malta is a consistent outlier, but otherwise these countries collectively account for close to three quarters of accession exports. ${ }^{11}$

Table $2 \mathrm{~b}$ shows that accession countries export much less to the United States and other countries with exchange regimes tied to the dollar, both in East Asia ${ }^{12}$ and other regions ${ }^{13}$. The United States purchases less than five percent of euro area exports of goods, except for Malta and Latvia. Accession countries also have low direct export links with other dollar bloc countries.

Table 2a:

Accession Country Exports to the Euro Bloc and the rest of the European Union, 2003

\begin{tabular}{|l|c|c|c|c|}
\hline & Euro Area & Other Euro Bloc & $\begin{array}{c}\text { non-Euro Area } \\
\text { European Union }\end{array}$ & $\begin{array}{c}\text { Total Euro Bloc } \\
\text { and EU }\end{array}$ \\
\hline Bulgaria & 50.7 & 3.1 & 7.1 & 60.9 \\
\hline Cyprus & 31.5 & 0.1 & 34.6 & 66.2 \\
\hline Czech Republic & 61.7 & 0.2 & 22.6 & 84.5 \\
\hline Estonia & 39.7 & 0.0 & 36.9 & 76.6 \\
\hline Hungary & 62.9 & 1.3 & 15.7 & 79.9 \\
\hline Latvia & 27.4 & 0.0 & 47.0 & 74.4 \\
\hline Lithuania & 33.1 & 0.0 & 36.0 & 69.2 \\
\hline Malta & 25.8 & 0.2 & 12.5 & 38.5 \\
\hline Poland & 57.7 & 0.3 & 22.4 & 80.4 \\
\hline Slovakia & 58.8 & 0.6 & 26.7 & 86.0 \\
\hline Slovenia & 57.6 & 7.3 & 11.5 & 76.4 \\
\hline
\end{tabular}

11 Non-euro area European countries are Denmark, Sweden, the UK, and the 10 accession countries. As documented in Padoa-Schioppa (2004), 'Other euro bloc countries' are countries with an exchange rate policy of pegging to the euro specifically Bosnia-Herzegovina, Montenegro, Serbia, New Caledonia, Benin, Burkina Faso, Cameroon, Cape Verde, Central African Republic, Chad, Comoros, Côte d'Ivoire, Equatorial Guinea, Gabon, Guinea-Bissau, Mali, Niger, Republic of Congo, Senegal, and Togo.

${ }^{12}$ Cambodia, China, Hong Kong, Indonesia, Korea, Malaysia, Philippines, Thailand, Vietnam.

${ }^{13}$ We define "Other Dollar Bloc" as: Australia, New Zealand, Canada, Argentina, Bolivia, Brazil, Chile, Colombia, Costa Rica, Dominican Republic, Ecuador, El Salvador, Guatemala, Honduras, Mexico, Nicaragua, Panama, Paraguay, Peru, Uruguay, Venezuela 
Table 2b: Accession Country Exports to the United States and the Dollar Bloc, 2003

\begin{tabular}{|l|c|c|c|c|}
\hline Country & United States & East Asia & $\begin{array}{c}\text { Other Dollar } \\
\text { Bloc }\end{array}$ & $\begin{array}{c}\text { Total Dollar } \\
\text { Bloc }\end{array}$ \\
\hline Bulgaria & 6.1 & 1.4 & 1.6 & 9.0 \\
\hline Cyprus & 1.6 & 1.4 & 0.6 & 3.7 \\
\hline Czech Republic & 3.0 & 1.3 & 0.9 & 5.2 \\
\hline Estonia & 3.3 & 1.6 & 1.3 & 6.2 \\
\hline Hungary & 6.3 & 1.7 & 1.1 & 9.0 \\
\hline Latvia & 10.4 & 0.7 & 0.7 & 11.8 \\
\hline Lithuania & 5.5 & 1.0 & 0.9 & 7.4 \\
\hline Malta & 12.1 & 15.2 & 1.6 & 29.0 \\
\hline Poland & 2.7 & 1.1 & 1.3 & 5.2 \\
\hline Slovakia & 4.9 & 0.7 & 0.5 & 6.1 \\
\hline Slovenia & 3.6 & 0.6 & 0.9 & 5.1 \\
\hline
\end{tabular}

Source: International Monetary Fund, Direction of Trade Statistics

Available data does not differentiate invoicing patterns as accession country exports to the euro area versus exports to other Europe and euro-bloc countries. Speculatively, given the dominance of trade with the rest of Europe in accession exports, these might also be the markets where accession countries are invoicing in euros. Consider the following hypothetical invoicing. Suppose that 100 percent of accession country trade with the euro area is invoiced in euros (an overstatement given the composition of this trade across differentiated versus homogeneous and commodity-type goods) and 100 percent of accession country trade with the United States is invoiced in dollars. The implied use of euros on accession country exports to other countries are shown in Chart 5, with these residual exports primarily directed at the rest of Europe. ${ }^{14}$ These computations imply that euro invoicing occurs on an average of 37 percent of accession exports to countries outside of the euro area and the United States. The variation across countries is large. Lithuania has zero implied euro invoicing on transactions outside the euro area, while Hungary and Slovenia have euro invoicing have shares exceeding 70 percent on export transactions directed outside the United States and euro area.

\footnotetext{
14 The share of euro use in extra-euro area exports is constructed as: (share of total exports invoiced in euros - share of total exports sent to euro area) / (100-share of total exports sent to the euro area and the United States), where all shares are in percent.
} 
Such statistics can be compared with invoicing patterns of countries already within the euro area, where the euro serves as the producer currency as well as a potential vehicle currency elsewhere. Starting with data on extra-euro area trade, euros are used in invoicing approximately 50 percent of extra euro-area exports. Under the assumption that trade with the United States is exclusively in dollars, the computation implies that euros are used in invoicing nearly 60 percent of the remaining exports. The range is from a low of 30 percent for Greece to about 75 percent for Germany.

Chart 5: Euro Invoicing share in Exports to countries other than the euro zone and United States, 2003*

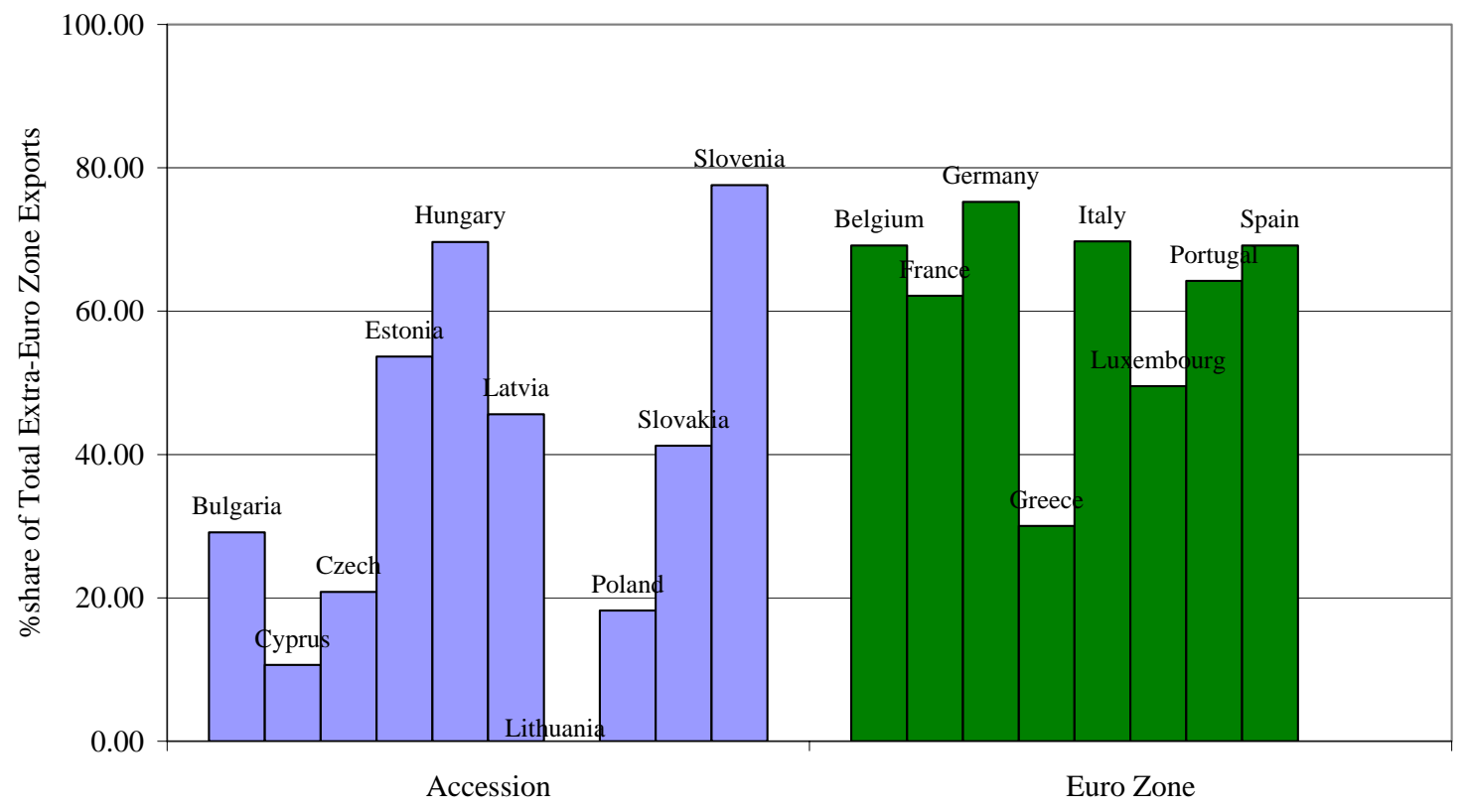

* * With Accession country shares estimated assuming that $100 \%$ of exports to the euro zone are invoiced in euros and $100 \%$ of exports to the U.S. are invoiced in dollars. Slovakia data for 2002. Lithuania adjusted to zero from an estimated share of $-7.4 \%$.

The Composition of Accession Country Exports. The previous section focused exclusively on destination markets, without taking into account the composition of trade. Recall that the theoretical model predicts a dominant role of herding in invoice currency choice for producers whose goods face high elasticities of substitution in export markets. To highlight this point, this section categorizes accession country exports according to whether they are differentiated " $N$ " (as are many manufactured goods), have uniform prices referenced in industry periodicals " $R$ " (used for uniform goods not widely traded enough to have a world market, such as paper), or are considered Walrasian "W", which are homogeneous goods, mainly commodities such as ore with world market prices, typically quoted in a single currency and traded on organized exchanges. 
Box 1 presents examples of Walrasian and reference priced goods, with specific reference to exports of accession countries. For this construction of export composition shares, I use Rauch (1999) indices, which classify industries into N, R, or W groups, and apply these indices to sort country-specific 4-digit SITC data on exports for each accession country. Table 3 presents the resulting shares of differentiated $(\mathrm{N})$, reference priced $(\mathrm{R})$, and organized exchange traded $(\mathrm{W})$ goods in each country's exports.

Table 3 The Composition of Accession Country Exports in 2003, by Pricing Method

\begin{tabular}{|l|c|c|c|c|c|}
\hline Country & $\begin{array}{c}\text { Differentiated } \\
\text { "N" }\end{array}$ & $\begin{array}{c}\text { Reference- } \\
\text { Priced " } R \text { " }\end{array}$ & $\begin{array}{c}\text { Organized } \\
\text { Exchange “W” }\end{array}$ & \multicolumn{2}{|c|}{ Total $R+W$ share } \\
\cline { 5 - 6 } & 64.9 & 20.5 & 14.7 & 42.5 & 35.1 \\
\hline Bulgaria & 61.7 & 30.6 & 7.7 & 61.9 & 38.3 \\
\hline Czech Republic & 83.0 & 14.5 & 2.5 & 19.5 & 17.0 \\
\hline Estonia & 70.2 & 26.0 & 3.8 & 35.0 & 29.8 \\
\hline Hungary & 81.8 & 13.7 & 4.5 & 19.8 & 18.2 \\
\hline Latvia & 64.8 & 30.1 & 5.1 & 36.1 & 35.2 \\
\hline Lithuania & 68.2 & 25.6 & 6.2 & 52.2 & 31.8 \\
\hline Malta* & 80.3 & 6.3 & 13.4 & 19.7 & - \\
\hline Poland & 75.5 & 18.7 & 5.8 & 28.5 & 24.5 \\
\hline Slovakia & 82.0 & 14.6 & 3.4 & 22.0 & 18.0 \\
\hline Slovenia & 80.8 & 16.7 & 2.5 & 21.9 & 19.2 \\
\hline
\end{tabular}

* Source: Trade data from UN Comtrade, and author’s calculations. Malta data from 2000.

Differentiated products account for 62 to 83 percent of accession country exports. Organized exchange traded goods, often priced in dollars, are typically a small proportion of the remaining exports and are generally less than 8 percent of exports. ${ }^{15}$ Reference priced goods are between 15 percent and 30 percent of accession country exports, with shares for Cyprus, Estonia, Latvia, and Lithuania all above 25 percent. All of the accession countries had reduced shares of the more

${ }^{15}$ Differentiated products comprise about three quarters of 2003 imports. 
homogeneous goods (the R+W share) between 2000 and 2003. Declines were large for Cyprus and Lithuania.

Taken together the shares of reference-priced and organized exchange traded goods represent between 17 and 35 percent of accession country exports. While reductions in these shares since 2000 may have accounted for some of the decline in dollar use in invoicing exports of accession countries, $\mathrm{R}+\mathrm{W}$ goods still represent a large portion of accession country exports. For the most part, the observed declines are too small to explain shifts away from dollars in accession country export invoicing. Recall that the evidence on invoicing changes between 2000 and 2003 was only available for Bulgaria, Czech Republic, and Latvia. Accounting for the changing share of trade with the euro area, Latvia and Bulgaria had larger increases in invoicing in euros, while the Czech Republic had relatively small changes. This pattern is not matched by $\mathrm{R}+\mathrm{W}$ share declines across these three countries, where the Czech Republic had the largest change, Latvia some change, and Bulgaria very little change in composition of exports.

If these $\mathrm{R}+\mathrm{W}$ goods are invoiced in dollars in European markets, the model would suggest that many accession countries under-utilized dollars in invoicing exports in 2003. In some cases, the share of dollars used in invoicing total country exports is below the share of $\mathrm{R}+\mathrm{W}$ goods in the export basket (Czech Republic, Estonia, Hungary, Latvia, Slovakia, Slovenia). Even though accession country exporters conduct much of their trade with other European countries, they still compete with producers from around the world, many of whom are likely invoicing these types of goods in dollars. The examples of pricing of copper, aluminum and paper pulp, shown in Box 1, illustrate the pervasiveness of dollar pricing on some products in these categories. If the accession country exporters are in fact invoicing less of their $\mathrm{R}+\mathrm{W}$ type goods in dollars and instead invoicing these goods in euros, they may be exposing themselves to excess profit risk under circumstances of movements of the euro-dollar exchange rate. 


\title{
Box 1 Sample industry profiles for reference priced and world market priced goods
}

\author{
Unwrought Copper: a world market priced good.
}

Rauch classifies commodity 6821, “Copper and copper alloys, refined or not, unwrought” (SITC rev. 2 4digit classification), as a world priced good. Accession countries export large quantities of unwrought copper, \$942 million in 2003 (UN Comtrade), representing 0.5 percent of total Accession country exports.

The main world market for unwrought copper is the London Metal Exchange (LME), with industry profiles and reports referencing the LME prices. The official prices quoted by the LME are in U.S. dollars per ton. The LME also trades unwrought aluminium, which also is a major export for the accession countries (\$740 million in 2003), suggesting potential similarities in pricing and invoicing across both commodity categories.

The largest accession copper exporters are Bulgaria and Poland (unwrought copper comprises 6.0\% of Bulgaria's total exports by value in 2003). Almost all of Bulgaria's copper is smelted at Pirdop, which is owned by Umicore, a Belgian company. The smelt copper is then exported to Umicore's headquarters in Belgium to be refined. So, Bulgaria’s "export" prices are transfer prices not market prices, subject to qualification because they represent transfers within a corporation.

Poland's main copper producer is KGHM Polska Miedz, which supplies 6\% of the world's copper according to AME Mineral Economics. KGHM posts a lot of information about its pricing structure on its website. They base their price on the LME and add a "producers premium" which is based on the annual price announcements of Codelco (the biggest world copper producer), which are also made in dollars. KGHM reports that the vast majority of copper sales are based on annual contracts where buyers agree to buy a certain tonnage a month whatever the market conditions, then pay each month based on the average market price over that month. A small share of sales is made with "spot contracts" to deal with unexpected shifts in supply or demand.

\section{Paper: a reference priced good.}

Paper is another major export for a number of the accession countries, including Estonia (2.5 percent of total exports in 2003), Poland (2.1 percent), Slovakia (2.0 percent), and Slovenia (1.8 percent). Pricing information is a little vaguer for this industry because, by definition, there is not an open world market with frequently published price quotes. Industry publications, such as Paperloop and Pulp \& Paper Week, list monthly or quarterly market prices for various grades of paper, with these prices usually only made available to subscribers.

These periodicals publish prices for specific markets. Newsprint and pulp, both "W"-type goods, only have world markets listed, but the industry publications list printing and writing paper prices separately for North American, European, and sometimes Asian markets. When specific prices are mentioned, Asian markets and North American markets were quoted in U.S. dollars and Europe markets were quoted in euros. One publication listed a full table of prices from FOEX (Finnish Options Exchange) which were all in euros.

London Metal Exchange: http://www.lme.co.uk/

AME Mineral Economics: http://www.ame.com.au/

KGHM Polska Miedz: http://www.kghm.pl/en/index.php

Paperloop: http://www.paperloop.com/

Pulp \& Paper Week: http://www.pulpandpaperonline.com/ 
Macroeconomic covariances and hedging in export invoicing. The theory exposition of Section II emphasizes that specific macroeconomic covariances could impact producer pricing and invoicing, with these effects potentially economically important for producers of goods with lower elasticities of substitution. In our empirical exercise, these goods are classified and interpreted as the "N" goods, i.e. the ones that are differentiated products mostly found within manufacturing. From equations (5) to (7), the key hedging terms are the covariances between the alternative exchange rates for the exporter currency and $m_{e d}=w_{e}+\frac{1-\alpha}{\alpha} c_{d}$. Recall that $w_{e}$ is the quarter-to-quarter percent change in an index of production costs, $\alpha$ is a parameter indicating the degree of diminishing returns to scale in production, and $c_{d}$ captures the business cycle conditions of the destination market. The herding role in invoicing exports is given by the term $(1-\Omega) \rho\left(m_{e d}, s_{e d}\right)$ for the destination market currency, and by $(1-\Omega) \rho\left(m_{e d}, s_{e v}\right)$ for a vehicle currency on transactions with the destination market $d$.

We derive values for $w_{e}, c_{d}, m_{e d}$ using data spanning the period 1980Q1-2005:Q3 and primarily drawn from Eurostat and the International Financial Statistics (IMF) ${ }^{16}$. We confine our analysis to a discussion of the dollar and the euro as currency alternatives, and to the United States, the euro area, the rest of Europe, and Asia as destination markets. For each accession country exporter, wages $w_{e}$ are quarter-to-quarter percent changes in nominal data. ${ }^{17}$ Exchange rates are nominal and bilateral between each accession country currency and either the euro or the U.S. dollar. Exporter wages are the proxy for marginal costs, thereby excluding by construction consideration of correlations that might arise through the costs of imported inputs into production. To the extent that these imported inputs are commodities, the analysis will likely understate the correlation between a true $w_{e}$ and $s_{e v}$, where the dollar is the vehicle currency. Alternatively, if some production inputs are imported from euro area countries and euro priced, the covariance between accession marginal costs and euro exchange rates may be understated.

\footnotetext{
${ }^{16}$ Date ranges for individual countries vary, with data for the Accession countries generally only available after 1992. Details of data availability and sources are in the appendix.

${ }^{17}$ Data from Eurostat cover all goods and services trade excluding public administration services (NACE industries $\mathrm{C}$ to $\mathrm{K}$ ). Data from IFS vary somewhat in industries covered depending on available data from each country, but give preference to indices that cover salaried employees as well as wage earners.
} 
Four destination markets $d$ for accession country exports are introduced: the euro area, the non-euro area European Union, the United States, and Asia. ${ }^{18}$ Destination market demand conditions, $c_{d}$, are constructed as quarter-to-quarter percent changes in real consumption expenditure for each of the four destination markets. ${ }^{19}$ Thus, for each country, four values of $m_{e d}$ are constructed, each corresponding to the relevant destination market and each construction assuming a value for $\alpha$ equal to $0.65 .^{20}$ Each series $m_{e d}$ is then regressed against the accession country exchange rates with respect to the dollar and the euro, the two $s_{e v}$ alternatives, according to the following regression:

$$
m_{e d, t}=a_{o}+a_{1} \text { trend }+a_{2} \text { local currency per dollar }{ }_{t}+a_{3} \text { local currency per euro }{ }_{t}+\varepsilon_{t}
$$

where the exchange rate terms are in quarter to quarter percent changes and $\varepsilon_{t}$ is a regression residual. According to the theory, a larger correlation with a specific currency will make that currency a better internal profit hedge and more appealing in international trade transactions with a particular destination market.

It is possible that currency choices based on hedging motives evolve over time, as the economic correlations evolve. For example, correlations may change as the accession countries draw closer to the euro area in international trade activity, economic policy, and exchange rate regime arrangements. To capture the possibility of changes over time in the attractiveness of the dollar versus the euro as invoicing currencies for smoothing exporter profits, we examine econometrically whether estimated $a_{2}$ and $a_{3}$ have changed over time. For this analysis a variable dummy is defined as equal to 1 during and after 2000 and zero otherwise and is interacted with the exchange rate terms in the regression given by (9).

$$
\begin{aligned}
m_{\text {ed,t }}= & a_{o}+a_{1} \text { trend }+\left(a_{2}+d_{2} * d u m m y\right) \text { local currency per dollar }{ }_{t} \\
& +\left(a_{3}+d_{3} * \text { dummy }\right) \text { local currency per euro }{ }_{t}+\varepsilon_{t}
\end{aligned}
$$

\footnotetext{
18 “Asia” is a GDP-weighted average of China, Hong Kong, India, Indonesia, Japan, Malaysia, the Philippines, Singapore, South Korea, Taiwan, and Thailand.

${ }^{19}$ Consumption data are from IFS, Eurostat, national sources, and the Federal Reserve Board. Consumption is either reported in real terms or reported in nominal terms and then deflated with a national CPI. Source data details are available on request.

${ }^{20}$ The value $\alpha=0.65$ correspondences to a markup of 20 percent over production costs.
} 
Table 4: Dollar versus Euro Invoicing for Stabilizing Accession Country Export Profits Early Period (1992-1999) $\dagger$

\begin{tabular}{|c|c|c|c|c|}
\hline & $\begin{array}{l}\text { US as export } \\
\text { destination }\end{array}$ & $\begin{array}{c}\text { Euro area as } \\
\text { destination }\end{array}$ & $\begin{array}{l}\text { Other Europe } \\
\text { as destination }\end{array}$ & $\begin{array}{c}\text { Asia as export } \\
\text { destination }\end{array}$ \\
\hline & $\begin{array}{c}\text { Regression } \\
\text { coefficient } \\
\rho\left(m_{\text {edus }}, S_{\text {edollar }}\right) \\
-\rho\left(m_{\text {edus }}, s_{e, \text { euro }}\right) \\
\end{array}$ & $\begin{array}{c}\text { Regression } \\
\text { coefficient } \\
\rho\left(m_{\text {edeuroz }}, s_{\text {edollar }}\right) \\
-\rho\left(m_{\text {edeuroz }}, s_{\text {e,euro }}\right)\end{array}$ & $\begin{array}{c}\text { Regression } \\
\text { coefficient } \\
\rho\left(m_{\text {edotherEU }}, S_{\text {edollar }}\right) \\
-\rho\left(m_{\text {edotherEU }}, S_{e, \text { euro }}\right)\end{array}$ & $\begin{array}{c}\text { Regression } \\
\text { coefficient } \\
\rho\left(m_{\text {edotherEU }}, S_{\text {edollar }}\right) \\
-\rho\left(m_{\text {edotherEU }}, S_{\text {e,euro }}\right)\end{array}$ \\
\hline Bulgaria & -0.54 & -0.49 & -0.46 & -1.24 \\
\hline Cyprus & 0.71 & 0.66 & 0.67 & 0.68 \\
\hline Czech & -0.74 & -0.71 & -0.71 & -0.98 \\
\hline Estonia & 0.00 & 0.09 & 0.06 & -0.67 \\
\hline Hungary & 0.18 & 0.19 & 0.21 & 0.04 \\
\hline Latvia & -0.15 & -0.06 & -0.10 & -0.30 \\
\hline Lithuania & $1.57 *$ & $1.58 *$ & 1.52* & 1.28 \\
\hline Malta & 0.09 & 0.03 & 0.04 & 0.10 \\
\hline Poland & -0.28 & -0.27 & -0.25 & -0.26 \\
\hline Slovakia & -1.10 & -1.07 & -1.04 & -1.44 \\
\hline Slovenia & 0.42 & 0.52 & 0.48 & -0.22 \\
\hline
\end{tabular}

Late Period (2000-2005)

\begin{tabular}{|c|c|c|c|c|}
\hline & $\begin{array}{l}\text { US as export } \\
\text { destination }\end{array}$ & $\begin{array}{l}\text { Euro area as } \\
\text { destination }\end{array}$ & $\begin{array}{l}\text { Other Europe } \\
\text { as destination }\end{array}$ & $\begin{array}{c}\text { Asia as export } \\
\text { destination }\end{array}$ \\
\hline & $\begin{array}{c}\text { Regression } \\
\text { coefficient } \\
\rho\left(m_{\text {edus }}, s_{\text {edollar }}\right) \\
-\rho\left(m_{\text {edus }}, s_{e, \text { euro }}\right) \\
\end{array}$ & $\begin{array}{c}\text { Regression } \\
\text { coefficient } \\
\rho\left(m_{\text {edeuroz }}, s_{\text {edollar }}\right) \\
-\rho\left(m_{\text {edeuroz }}, s_{\text {e,euro }}\right)\end{array}$ & $\begin{array}{c}\text { Regression } \\
\text { coefficient } \\
\rho\left(m_{\text {edotherEU }}, S_{\text {edollar }}\right) \\
-\rho\left(m_{\text {edotherEU }}, S_{e, \text { euro }}\right)\end{array}$ & $\begin{array}{c}\text { Regression } \\
\text { coefficient } \\
\rho\left(m_{\text {edotherEU }}, S_{\text {edollar }}\right) \\
-\rho\left(m_{\text {edotherEU }}, S_{\text {e,euro }}\right)\end{array}$ \\
\hline Bulgaria & 0.57 & 0.54 & 0.54 & 0.52 \\
\hline Cyprus & 0.71 & 0.66 & 0.67 & 0.68 \\
\hline Czech & 1.15 & 1.11 & 1.12 & 1.08 \\
\hline Estonia & 1.05 & 1.02 & 1.02 & 0.96 \\
\hline Hungary & -0.90 & -0.93 & -0.92 & $-0.96 *$ \\
\hline Latvia & $-1.14 \ddagger$ & $-1.14 \ddagger$ & $-1.14 \ddagger$ & $-1.32 \ddagger$ \\
\hline Lithuania & -0.11 & -0.14 & -0.14 & -0.18 \\
\hline Malta & 0.09 & 0.03 & 0.04 & 0.10 \\
\hline Poland & 0.50 & 0.45 & 0.47 & 0.38 \\
\hline Slovakia & 0.84 & 0.82 & 0.82 & 0.77 \\
\hline Slovenia & 0.37 & 0.33 & 0.33 & 0.29 \\
\hline
\end{tabular}

$\dagger$ Exact dates differ by country. Details in appendix table 4 .

\$ The coefficients on one or both exchange rates are significant, although the difference between the two is not. Coefficients for each exchange rate are reported in Appendix table 2.

Note: Regression coefficients on local currency per dollars versus local currency per euros. .

$*$, **, and ${ }^{* * *}$ denote significance at 10,5 , and 1 percent levels, respectively.

Table 4 regressions have quarterly data, but the number of observations used is limited by the availability of wage data for the accession countries. Since data for many countries is only 
available after 1992, the degrees of freedom are low: consequently, we consider the findings as indicative but not conclusive. The numerical entries in the table are the difference between estimated coefficients, $a_{2}$ minus $a_{3}$, on the dollar and euro exchange rates with local currencies in each period. A positive and significant coefficient would indicate whether the dollar would, as an invoicing currency, provide better stabilization of profits of the accession country exporter to a specific destination. ${ }^{21} \mathrm{~A}$ negative and significant value on $a_{2}$ minus $a_{3}$ means that the invoicing decision by an accession country exporter export transaction should favor the euro.

The results reported in Table 4 show that, in general, the regression coefficients are statistically insignificant. This result indicates that accession country exporters generally should be indifferent to the dollar or euro as invoicing currencies on these transactions. One exception is Lithuania, which has a significant dollar preference in all markets during the early, pre-2000, period and an insignificant euro hedging preference since 2000. In the later period, Latvia has significant negative correlations between $m_{e d}$ and both the euro and dollar exchange rates, suggesting that neither currency is a useful hedge. The difference between $a_{2}$ and $a_{3}$ favors the euro, but is insignificant. The final significant observation is Hungary's preference for the euro as a hedging currency in the later period for the Asian market only. In the other markets since 2000, Hungary also has a euro preference, but it is not significant.

As a broad pattern, the preponderance of negative coefficients (and recognizing that most of the coefficients are statistically insignificant) suggests that more accession countries have a euro preference prior to 2000 than after, but only Latvia has a euro preference in both periods. Bulgaria, the Czech Republic, Poland, and Slovakia have a euro preference early, then move to a dollar preference since 2000. Hungary and Lithuania have a dollar preference early moving to a euro preference later. Estonia and Slovenia prefer the dollar as a hedging currency throughout, with the exception of the early period in the Asian market. Cyprus and Malta have no data prior to 2000, but exhibit a dollar preference in the later period. ${ }^{22}$

\footnotetext{
${ }^{21}$ We abstract from country-specific $\Omega$, which is related to the shares of $\mathrm{R}+\mathrm{W}$ goods in total exports.

${ }^{22}$ The early period results for Bulgaria, Estonia, and Slovenia are particularly weak because they only have only a few years of data prior to 2000. For Bulgaria, the early period covers only 1998 and 1999; Estonia and Slovenia have data beginning in 1996. The other countries have data stretching back to at least 1993, and into the early 1980s for Hungary and Poland.
} 
The role of exchange rate regimes. The accession countries had a variety of currency arrangements since the early 1990s, the period covered by our correlation analysis. These shifting exchange rate regimes may contribute to the changing patterns of dollar and euro preferences as a hedging currency.

According to the exchange rate regime classifications of Reinhart and Rogoff (2002) and Levi-Yeyati and Sturzenneger (2005), seven of the countries we examine have been closely aligned with the euro, or earlier the DM, throughout the period we examine. These countries, Bulgaria, Cyprus, Estonia, Hungary, Malta, Slovakia, and Slovenia, tied their currencies either exclusively to the DM or euro or to a basket of currencies dominated by the DM or euro. The Czech Republic pegged their currency to a DM-dominated basket until 1997 and has been floating since them. Poland first had a loose crawling peg to the dollar, and then to the DM and euro, and has been floating since 2000. Slovakia also began with a loose crawling peg to a $\mathrm{DM} /$ dollar basket, then begen effectively pegging to the euro in 1999. Lithuania was the only country exclusively pegged to the dollar before switching to the euro in 2002 as part of the process of joining the euro zone. Latvia has also been primarily associated with the dollar, pegging to the SDR, a basket in which the dollar has the strongest weight, throughout the period.

In general, the countries that have experienced significant shifts in exchange rate policy between the early and late period are also the countries moved from one currency to the other as a preferred hedging currency (although these effects are typically statistically insignificant). Another reason for covariance changes could be if "other Europe”, as a destination markets for accession goods, had business cycles that covaried more directly with the rest of the euro area due to their increased use of the euro. Such effects could continue to be monitored over time.

Overall empirics of accession country invoicing. This final subsection pulls together the insights from the prior sections to generate suggestive conclusions on accession country export invoicing. Table 5 provides perspective on whether the use of dollars in export invoicing appears to be relatively high or low, while Table 6 provides similar intuitions concerning euro use in invoicing accession country exports. 
Table 5: 2003 Dollar Invoicing on Exports Higher or Lower than Predicted?

\begin{tabular}{|c|c|c|c|c|c|c|}
\hline & \multirow[b]{2}{*}{$\begin{array}{l}\text { Observed } \\
\text { dollar } \\
\text { invoicing } \\
\text { share* }^{*}\end{array}$} & \multirow[b]{2}{*}{$\begin{array}{l}R+W \\
\text { share in } \\
\text { exports }\end{array}$} & \multirow[b]{2}{*}{$\begin{array}{l}\text { Dollar bloc } \\
\text { share in } \\
\text { exports }\end{array}$} & \multicolumn{2}{|c|}{ Hedging consideration favoring dollar? ${ }^{+}$} & \multirow{2}{*}{$\begin{array}{l}\text { @ Is dollar } \\
\text { share in } \\
\text { invoicing } \\
\text { lower than } \\
\text { theoretically } \\
\text { optimal? }\end{array}$} \\
\hline & & & & $\begin{array}{c}\text { On exports } \\
\text { to euro zone } \\
\text { and other Europe }\end{array}$ & $\begin{array}{c}\text { On exports to } \\
\text { Asia }\end{array}$ & \\
\hline Bulgaria & 44.5 & 35.1 & 9.0 & no & no & no \\
\hline Cyprus & 44.7 & 38.3 & 3.7 & no & no & no \\
\hline Czech Republic & 14.7 & 17.0 & 5.2 & no & no & yes \\
\hline Estonia & 8.5 & 29.8 & 6.2 & no & no & yes \\
\hline Hungary & 12.2 & 18.2 & 9.0 & no & no & yes \\
\hline Latvia & 32.1 & 35.2 & 11.8 & no & no & yes \\
\hline Lithuania & -- & 31.8 & 7.4 & no & no & -- \\
\hline Malta & -- & -- & 29.0 & no & no & -- \\
\hline Poland & 29.9 & 24.5 & 5.2 & no & no & no \\
\hline Slovakia & 11.6 & 18.0 & 6.1 & no & no & yes \\
\hline Slovenia & 9.6 & 19.2 & 5.1 & no & no & yes \\
\hline
\end{tabular}

* Dollar share data from 2002 instead of 2003; late sample Table 4 results used in the hedging columns.

-- data unavailable

+ Only statistically significant results reported, as "favored" using "Late period" coefficients from Table 4

@ Is [( $\mathrm{R}+\mathrm{W}$ share in exports) plus (dollar bloc share in exports) (1-( $\mathrm{R}+\mathrm{W}$ tradeshare) $)$ plus "yes” in hedging considerations] in excess of the observed dollar invoicing share?

Source: Trade data from UN Comtrade, author's calculations; IMF, Direction of Trade Statistics; individual country sources (details in Appendix Table 2).

The first data column of each table shows the observed shares of each currency in invoicing. The next columns address the "motives" for using the respective currencies in invoicing. The final column compares observed invoicing versus predictions from the theory. The second column presents the sum of reference priced and exchange-traded goods in a country's exports, while the third data column shows the share of the dollar bloc countries in exports. The last column pulls together the $\mathrm{R}+\mathrm{W}$, dollar bloc, and hedging considerations, and asks whether the use of dollars in a country's export invoicing is lower than what might be expected under the presumption that 1 ) $\mathrm{R}+\mathrm{W}$ goods are priced in dollars worldwide and 2) dollars are used in invoicing (non $\mathrm{R}+\mathrm{W}$ ) exports to dollar bloc countries. The share of dollars in export invoicing is lower than expected for the Czech Republic, Estonia, Hungary, Latvia, Slovakia, and Slovenia. 
Table 6 presents similar considerations, this time addressing the question of whether the actual share of euros in accession country invoicing is higher than expected by the framework. The predicted level is the all Europe share in accession country exports. In the first prediction column, this is net of the share of goods that are reference priced and traded on organized exchanges (which embeds an the assumption that all these latter goods may be priced in dollars); in the next prediction column, the euro invoicing share is compared with the share of country exports to Europe, ignoring composition.

Table 6: 2003 Euro Invoicing on Exports Higher or Lower than Predicted?

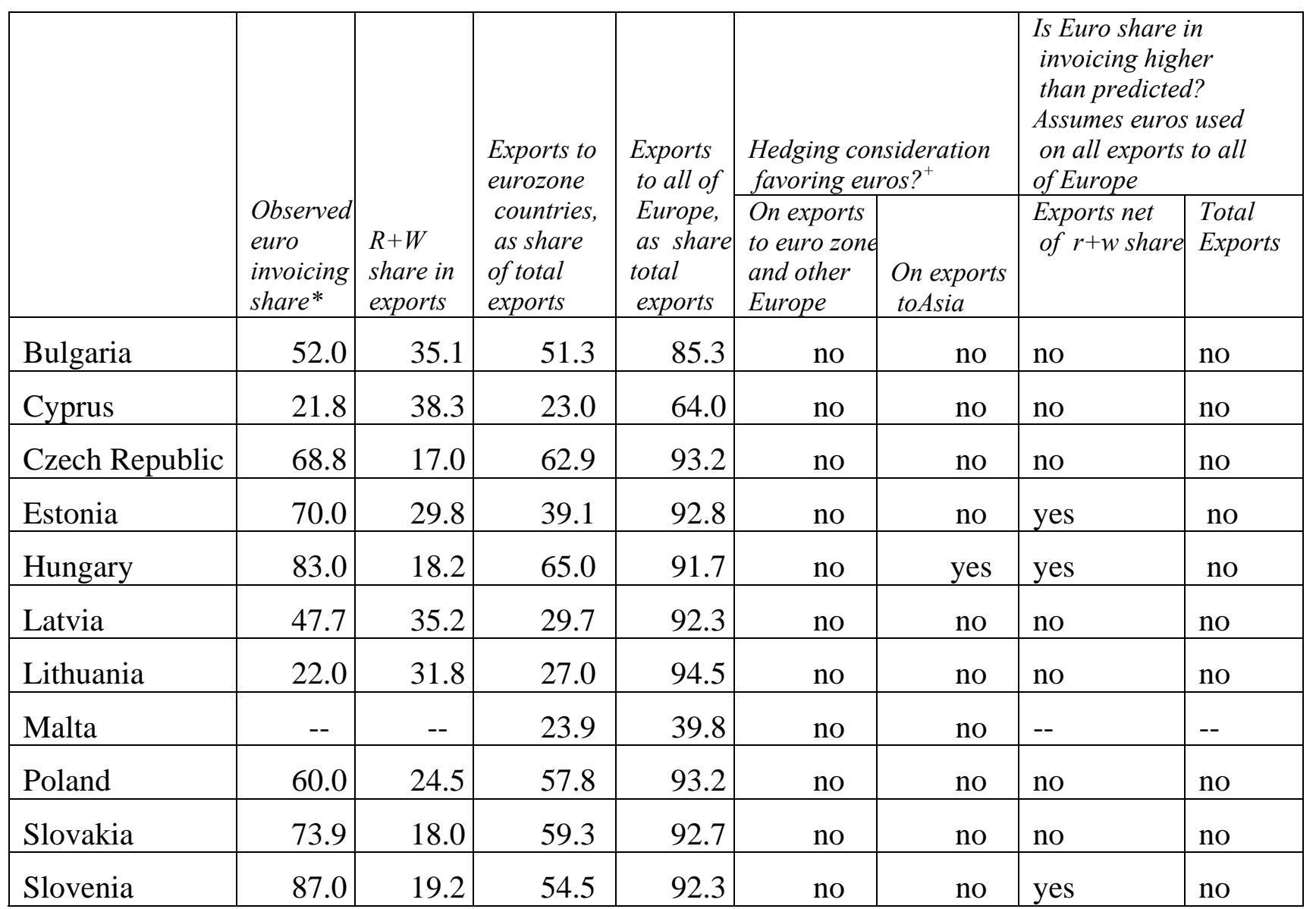

* Dollar share data from 2002 instead of 2003

-- data unavailable

+ Only statistically significant terms reported as favored, using "Late period" coefficients from Table 4. Hungary is the only country where the euro has a statistically significant hedge property, and only with respect to Asia. This consideration is precluded from computations in the last columns of the table.

In the net column, predicted share equals (all Europe export share) (1-RW share).

Source: Trade data from UN Comtrade, author's calculations; IMF, Direction of Trade Statistics; individual country sources (details in Appendix Table 2). 
In three of the ten countries for which we can do a comparison, the euro share is higher than expected based on the generous assumption that the euro is used on all trade with European partners, except for products that are homogeneous (which are assumed to trade in dollars). Those countries are Estonia, Hungary, and Slovenia. These countries are not "overusing" the euro under the even more generous assumption that all trade with European partners, including in homogeneous commodities is in euros, with no euro use on trade with other countries.

On balance, we conclude that Estonia, Hungary, and Slovenia have a greater tendency towards invoicing in euros than might be expected on the basis of trade with Europe being completely in euros and on the basis of the theoretical considerations that we have presented. These same countries, plus three others have dollar share in invoicing that are lower than predicted.

\section{Concluding remarks}

This paper has considered the issue of invoicing of trade transactions by accession countries. Many accession countries have moved sharply away from the U.S. dollar as a currency for invoicing trade, reaching levels that appear low compared with both the role of the United States as a trading partner and the composition of accession country trade. Suboptimal invoicing exposes producers to lower expected profits.

According to the theoretical exposition, whether or not an accession country is well suited to the euro in export invoicing should depend on the partners in trade, the composition of trade, and the structure of shocks facing that exporter. If accession countries turn more toward the euro area as a destination markets for exports, then the role of the euro in invoicing may increase. However, potentially more important for this consideration is the composition of these products and the norms in invoicing by competitors to accession countries. At least in the case of commodity exports and highly substitutable goods, dollar invoicing on some trade may continue to be desirable even within the euro area. If exchange rates between accession country currencies and the euro are stabilized or fixed, and if exchange rates with the dollar covary positively with local shocks (so that the accession country currency or euro depreciate against the

dollar when the accession country exporter faces high marginal costs), the model predicts greater use of dollars in invoicing euro area trade even as exchange rates are fixed with respect to the 
euro area. Alternatively, if exchange rates with the dollar covary negatively with local shocks (so that the accession country currency or the euro appreciates against the dollar when the accession country exporter faces high marginal costs), the model predicts a further movement away from accession country invoicing in dollars on euro area trade when exchange rates are fixed with respect to the euro area.

A broader question for the suitability of the euro for the trade invoicing of accession countries stems directly from the force of herding in a particular currency in the destination market for goods sold. This paper has often used the presumption that the U.S. dollar is the vehicle currency on pricing many international trade transactions, especially in highly substitutable goods. Evidence from a range of countries and a range of markets has supported such an assumption. An important consideration, though, is that the theoretical arguments, made in a partial equilibrium analysis, do not pin down which single currency - for example, dollars or euros or an alternative- will be selected by market participants for such herding.

While this herding has in recent decades been via the U.S. dollar, the stability of this equilibrium is important to consider. In particular, it would be useful to determine what types of shocks could lead to an unseating of the dollar in its vehicle currency role. In theoretical work, the answer to this question depends on what modeling assumptions are made in order to move from our partial equilibrium solution to a general equilibrium solution. The role of transaction costs in trading in different currencies might be the drivers of the equilibrium choice. This point was exposited by Swoboda $(1968,1969)$, and then elegantly developed by Rey $(2001)$ in a threecountry general equilibrium model emphasizing that "thick market externalities" arise from a currency's large presence in global international trade and low transaction costs of exchange. Krugman (1980) importantly pointed to the presence of inertia in vehicle currency selection, arguing, as we have, that when a currency is established as the dominant one in a market, a particular firm has no incentive to invoice in an alternative currency as this would lead to higher transaction cost and more volatile sales because of movements in its price relative to its competitors'. Once a currency has acquired a prominent role, because of low transaction costs for instance, it may keep this role even if another currency with similarly low costs emerges.

The exclusive role of macroeconomic volatility considerations in invoicing have been emphasized in recent general equilibrium papers, as in by Bacchetta and vanWincoop (2005), Devereux, Engel and Storegaard (2004), Oi, Otani, and Shirota (2004), and Engel (2005). Yet, 
once a currency has been established as dominant in invoicing or as a vehicle currency and has lower transaction costs, the thick market externalities may make the conditions for overcoming the inertia difficult to satisfy.

Future theoretical work could bring these insights on transaction cost and volatility considerations together to yield predictions for the future optimality of invoicing in dollars, euros, or other currencies for exporters worldwide. Future work could also consider the conditions for segmented markets to arise in herding, perhaps leading to multiple dominant currencies in different subsets of industries or locations.

\section{References:}

Bacchetta, Philippe and van Wincoop, Eric. 2005. “A Theory of the Currency Denomination of International Trade.” Journal of International Economics, 67(2), pp. 295-319.

Campa, José and Goldberg, Linda. 2005. “Exchange Rate Pass-Through into Import Prices.” Review of Economics and Statistics, November, 87(4): pp. 679-690.

Campa, José Manuel, Linda S. Goldberg, and José M. González-Mínguez. 2005. “Exchange rate pass-through to import prices in the euro area” National Bureau of Economic Research Working Paper No.11632, September.

Devereux, Michael, Engel, Charles, and Storegaard, Peter. 2004. “Endogenous Exchange Rate Pass-Through when Nominal Prices are set in Advance.” Journal of International Economics, 63(2), pp. 263-291.

Engel, Charles. 2005. “Equivalence Results for Optimal Pass-Through, Optimal Indexing to Exchange Rates, and Optimal Choice of Currency for Export Pricing.” National Bureau of Economic Research Working Paper No. 11209, March.

European Central Bank. Review of the International Role of the Euro. 2001, 2002, 2005

Giovannini, Alberto. 1988. “Exchange Rates and Traded Goods Prices.” Journal of International Economics, 24(1-2), pp.45-68. 
Goldberg, Linda and Cedric Tille. 2005. "Vehicle Currency Use in International Trade." National Bureau of Economic Research Working Paper No. 11127, February.

Krugman, Paul. 1980. "Vehicle Currencies and the Structure of International Exchange.” Journal of Money, Credit and Banking, 12, pp. 513-526.

Levy-Yeyati, Eduardo and Federico Sturzenegger. 2005. "Classifying Exchange Rate Regimes: Deeds vs. Words." European Economic Review, 49(6), pp. 1603-1635.

McKinnon, Ronald. 1979. Money in International Exchange: The Convertible Currency System. Oxford University Press.

Oi, Hiroyuki, Akira Otani, and Toyoichiro Shirota. 2004. "The Choice of Invoice Currency in International Trade: Implications for the Internationalization of the Yen.” Monetary and Economic Studies, 22(1), pp.27-63.

Padoa-Schioppa, Tommaso. 2004. The Euro and Its Central Bank. MIT Press.

Portes, Richard and Helene Rey. 1998. "The Emergence of the Euro as an International Currency." Economic Policy, Vol. 13 No. 26, pp.305-343.

Rauch, James. 1999. “Networks versus Markets in International Trade.” Journal of International Economics, 48(1), pp. 7-35.

Reinhart, Carmen M. and Kenneth S. Rogoff. 2004. "The Modern History of Exchange Rate Arrangements: A Reinterpretation." Quarterly Journal of Economics, 119(1), pp. 1-48.

Rey, Helene. 2001. "International Trade and Currency Exchange." Review of Economic Studies, 68(2), pp. 443-464.

Swoboda, Alexander. 1969. "Vehicle Currencies and the Foreign Exchange Market: the Case of the Dollar”, in Robert Z. Aliber, Ed., The International Market for Foreign Exchange, Praeger Special Studies in International Economics and Development, New York: Frederick A. Praeger Publishers.

Swoboda, Alexander. 1968. "The Euro-Dollar Market: An Interpretation”, Essays in International Finance 64, International Finance Section, Princeton University. 
Appendix Table 1: Dollar and Euro Shares of Trade Invoicing in Euro Zone Countries

\begin{tabular}{|c|c|c|c|c|}
\hline \multicolumn{5}{|c|}{ Invoicing Patterns in 2000} \\
\hline & \multicolumn{2}{|c|}{ Exports } & \multicolumn{2}{|c|}{ Imports } \\
\hline & Euro Share & Dollar Share & Euro Share & Dollar Share \\
\hline Average: & 44.6 & 43.0 & 43.5 & 46.8 \\
\hline Belgium* & 46.7 & & 46.6 & \\
\hline France & 50.3 & 33.4 & 37.5 & 46.1 \\
\hline Greece* & 15.6 & 76.9 & 25.4 & 65.3 \\
\hline Italy & 66.2 & 24.8 & 59.8 & 34.3 \\
\hline Portugal & 39.6 & 38.9 & 47.9 & 40.0 \\
\hline Spain & 49.3 & 41.3 & 43.7 & 48.2 \\
\hline \multicolumn{5}{|c|}{ Invoicing Patterns in 2002} \\
\hline Average: & 50.7 & 36.0 & 49.5 & 38.8 \\
\hline Belgium & 53.9 & 31.9 & 54.4 & 33.5 \\
\hline France & 55.8 & 34.2 & 48.6 & 43.3 \\
\hline Germany & 49.0 & 31.6 & 48.0 & 34.5 \\
\hline Greece & 21.8 & 71.1 & 31.0 & 62.0 \\
\hline Italy† & 74.9 & 17.5 & 70.2 & 24.9 \\
\hline Luxembourg & 44.0 & 35.7 & 31.7 & 38.0 \\
\hline Portugal & 48.1 & 33.4 & 57.8 & 34.5 \\
\hline Spain & 58.1 & 32.8 & 54.7 & 39.5 \\
\hline
\end{tabular}

* data from 2001 instead of 2000, † data from 2003 instead of 2002

currency shares for euro zone countries are for extra-euro zone trade only except for Italy

All shares are for invoicing of goods and services combined except for Germany (goods only).

Source: ECB report and individual country sources (details in Appendix Table 2) 


\section{Appendix Table 2 Documentation on Currency Invoicing Data}

\begin{tabular}{|c|c|c|}
\hline Country & Euro Share Data Source & Dollar Share Data Source \\
\hline Bulgaria & $\begin{array}{l}\text { ECB publication, Review of the } \\
\text { International Role of the Euro, Jan } 2005\end{array}$ & Bulgarian National Bank \\
\hline Cyprus & from ECB, by special request & from ECB, by special request \\
\hline Czech Republic & Czech Statistical Office & Czech Statistical Office \\
\hline Estonia & $\begin{array}{l}\text { ECB publication, Review of the } \\
\text { International Role of the Euro, Jan } 2005\end{array}$ & from ECB, by special request \\
\hline Hungary & $\begin{array}{l}\text { ECB publication, Review of the } \\
\text { International Role of the Euro, Jan } 2005\end{array}$ & from ECB, by special request \\
\hline Latvia & Latvijas Banka (Latvian Central Bank) & Latvijas Banka (Latvian Central Bank) \\
\hline Lithuania & $\begin{array}{l}\text { ECB publication, Review of the } \\
\text { International Role of the Euro, Jan } 2005\end{array}$ & \\
\hline Malta & $\begin{array}{l}\text { ECB publication, Review of the } \\
\text { International Role of the Euro, Jan } 2005\end{array}$ & \\
\hline Poland & $\begin{array}{l}\text { ECB publication, Review of the } \\
\text { International Role of the Euro, Jan } 2005\end{array}$ & from ECB, by special request \\
\hline Slovakia & $\begin{array}{l}\text { ECB publication, Review of the } \\
\text { International Role of the Euro, Jan } 2005\end{array}$ & from ECB, by special request \\
\hline Slovenia & $\begin{array}{l}\text { ECB publication, Review of the } \\
\text { International Role of the Euro, Jan } 2005\end{array}$ & from ECB, by special request \\
\hline Belgium & $\begin{array}{l}\text { ECB publication, Review of the } \\
\text { International Role of the Euro, Jan } 2005\end{array}$ & from ECB, by special request \\
\hline France & from ECB, by special request & from ECB, by special request \\
\hline Germany & $\begin{array}{l}\text { ECB publication, Review of the } \\
\text { International Role of the Euro, Jan } 2005\end{array}$ & from ECB, by special request \\
\hline Greece & $\begin{array}{l}\text { ECB publication, Review of the } \\
\text { International Role of the Euro, Jan } 2005\end{array}$ & from ECB, by special request \\
\hline Italy & $\begin{array}{l}\text { Ufficio Italiano dei Cambi, by special } \\
\text { request }\end{array}$ & $\begin{array}{l}\text { Ufficio Italiano dei Cambi, by special } \\
\text { request }\end{array}$ \\
\hline Luxembourg & $\begin{array}{l}\text { ECB publication, Review of the } \\
\text { International Role of the Euro, Jan } 2005\end{array}$ & from ECB, by special request \\
\hline Portugal & from ECB, by special request & from ECB, by special request \\
\hline Spain & from ECB, by special request & from ECB, by special request \\
\hline
\end{tabular}




\section{Appendix Table 3 Documentation on Data for Covariance Calculations Series Codes and Data Availability for Exporter Countries}

NSA: Not Seasonally Adjusted; IFS: International Financial Statistics; Haver Analytics as data feed for Eurostat information, with associated data codes provided.

\begin{tabular}{|l|l|l|l|}
\hline Country & $\begin{array}{l}\text { Available } \\
\text { Dates }\end{array}$ & $\begin{array}{l}\text { Wages: index of wages in } \\
\text { all non-government } \\
\text { industries (all NSA) }\end{array}$ & $\begin{array}{l}\text { Dollar Exchange Rate: } \\
\text { local currency / U.S. dollar } \\
\text { (all IFS) }\end{array}$ \\
\hline Bulgaria & $\begin{array}{l}\text { 1998 Q1 - } \\
2005 \text { Q3 }\end{array}$ & $\begin{array}{l}\text { Haver, } \\
\text { L918WCMW@EUROSTAT }\end{array}$ & \$Q91800RF \\
\hline Cyprus & $\begin{array}{l}2000 \text { Q1 - } \\
2005 \text { Q3 }\end{array}$ & $\begin{array}{l}\text { Haver, } \\
\text { L423TCMW@EUROSTAT }\end{array}$ & \$Q91800RF \\
\hline Czech & $\begin{array}{l}\text { 1993 Q1 - } \\
2005 \text { Q1 }\end{array}$ & IFS, \$Q93565 & \$Q93500RF \\
\hline Estonia & $\begin{array}{l}\text { 1996 Q1 - } \\
2005 \text { Q3 }\end{array}$ & $\begin{array}{l}\text { Haver, } \\
\text { L939WCMW@EUROSTAT }\end{array}$ & \$Q93900RF \\
\hline Hungary & $\begin{array}{l}1979 \text { Q1 - } \\
2005 \text { Q3 }\end{array}$ & IFS, \$Q94465 & \$Q94400RF \\
\hline Latvia & $\begin{array}{l}1992 \text { Q1 - } \\
2005 \text { Q3 }\end{array}$ & IFS, \$Q94165 & \$Q94100RF \\
\hline Lithuania & $\begin{array}{l}\text { 1993 Q1 - } \\
2005 \text { Q3 }\end{array}$ & IFS, \$Q94665 & \$Q94600RF \\
\hline Malta & $\begin{array}{l}2000 \text { Q1 - } \\
2005 \text { Q3 }\end{array}$ & $\begin{array}{l}\text { Haver, } \\
\text { L181TCMW@EUROSTAT }\end{array}$ & \$Q18100RF \\
\hline Poland & $\begin{array}{l}1982 \text { Q1 - } \\
2005 \text { Q3 }\end{array}$ & IFS, \$Q96465 & \$Q96400RF \\
\hline Slovakia & 1993 Q1 - & IFS, \$Q93665 & \$Q93600RF \\
\hline Slovenia & $\begin{array}{l}\text { 1996 Q1 - } \\
2005 \text { Q3 }\end{array}$ & $\begin{array}{l}\text { Haver, } \\
\text { L961WCMW@EUROSTAT }\end{array}$ & \$Q96100RF \\
\hline
\end{tabular}

